\title{
A STRATEGY FOR THE RAPID IDENTIFICATION OF FUNGAL METABOLITES AND THE DISCOVERY OF THE ANTIVIRAL ACTIVITY OF PYRENOCINE A AND HARZIANOPYRIDONE
}

\author{
Laura P. Ióca ${ }^{a}$, Stelamar Romminger ${ }^{a, b}$, Mario F. C. Santos ${ }^{a}$, Karin F. Bandeira ${ }^{a}$, Fabiana T. Rodrigues ${ }^{a}$, Miriam H. \\ Kossuga $^{a}$, Karen J. Nicacio ${ }^{a}$, Everton L. F. Ferreira ${ }^{a}$, Raquel P. Morais-Urano ${ }^{a}$, Messias S. Passos ${ }^{\text {, }}$ Luciana K. Kohn ${ }^{c}$, \\ Clarice W. Arns ${ }^{d}$, Lara D. Sette ${ }^{\mathrm{e}}$ e Roberto G. S. Berlinck ${ }^{\mathrm{a}, *}$ \\ anstituto de Química de São Carlos, Universidade de São Paulo, 13560-970 São Carlos - SP, Brasil \\ ${ }^{\mathrm{b}}$ Life Sciences Institute, University of Michigan, 48109 Ann Arbor - MI, United States of America. \\ ${ }^{c}$ Universidade de São Francisco, 13045-510 Campinas - SP, Brasil \\ ${ }^{d}$ Laboratório de Virologia, Instituto de Biologia, Universidade Estadual de Campinas, CP 6109, 13083-970 Campinas - SP, Brasil \\ eDepartamento de Bioquímica e Microbiologia, Instituto de Biociências, Universidade Estadual Paulista Júlio de Mesquita Filho, \\ 13506-900 Rio Claro - SP, Brasil
}

Recebido em 18/12/2015; aceito em 10/05/2016; publicado na web em 26/05/2016

\begin{abstract}
The isolation and identification of bioactive metabolites from complex extracts obtained from microbial growth media is a time consuming, costly, and labor-intensive task. A strategy to rapidly identify secondary metabolites isolated from extracts obtained from the culture media of marine-derived and endophytic fungal strains is described. Identification was achieved by HPLC-UV-MS and ${ }^{1} \mathrm{H}$ NMR analyses in combination with data obtained from the Dictionary of Natural Products. Among the compounds identified, (-)-naphthoquinoneimine, citreorosein, emodin, pyrenocine A and harzianopyridone displayed moderate to potent antiviral activity. (-)-Naphthoquinoneimine was isolated as the enantiomer of its previously reported dextrorotatory congener, while 6,7-dihydroxy2,2-dimethyl-4-chromanone is herein reported for the first time as a natural product.
\end{abstract}

Keywords: fungal metabolites; rapid identification; dereplication; antiviral.

\section{INTRODUCTION}

Most fungal secondary metabolites are remarkably complex bioactive compounds. ${ }^{1,2}$ Although they were almost dismissed in biodiscovery programs between the 1960's and 1980's, the raise of molecular biology tools provided compelling evidence that the diversity of filamentous fungi secondary metabolism is astonishingly higher than originally thought. ${ }^{3}$ Such metabolites are very often the inspiration for the development of new drug lead scaffolds and biochemical tools, resulting from the fact that many of these compounds present unique ecological roles, particularly as antibiotics and as chemical mediators.

The isolation of bioactive fungal metabolites from complex and chemically diverse extracts is time and resources consuming, a labor-intensive task. The rapid identification of known natural products isolated from fungal extracts is essential to avoid the record and analysis of multiple 1D and 2D NMR experiments. This is particularly true when dereplication of secondary metabolites in extracts of biological matrixes is unfeasible by high-resolution and high-throughput chromatography-spectroscopy hyphenated tools, such as HPLC-HRMS, HPLC-NMR and related techniques..$^{3-7}$ Data obtained from joint UV, LRMS and ${ }^{1} \mathrm{H}$ NMR analyses only, and sometimes ${ }^{13} \mathrm{C}$ NMR, can be used in querying databases such as the Dictionary of Natural Products (DNP), Antimarin, MarinLit, and Molecular Networking, as an effective combination for the rapid identification of known structures. ${ }^{8,9}$ The rapid identification of secondary metabolites enables further assessment of structures of interest, particularly of unprecedentedly bioactive known compounds.

The discovery of antiviral natural products is currently of seminal interest considering the emergence and re-emergence of viral diseases such as dengue, and infections caused by chikungunya and zika

*e-mail: rgsberlinck@iqsc.usp.br viruses. Only fifty antiviral drugs are available to treat viral infections..$^{10}$ The majority of these antivirals was introduced into clinical use during the last two decades, and they were discovered due to the urgency in developing treatments for the Human Immunodeficiency Virus (HIV) infection. ${ }^{10}$ Only a handful of antiviral compounds have been discovered from marine-derived fungi. These include sansalvamide A (1), produced by Fusarium sp., which exhibits antiviral activity against poxvirus (MCV), ${ }^{11}$ as well as halovirs A-E (2-6), produced by Scytalidium sp., and active against Herpes Simplex Virus Types 1 and 2 (HSV). ${ }^{12}$

The discovery of microbial secondary metabolites in Brazil increased considerably during the last 15 years. However, when considering all the microbial secondary metabolites isolated by Brazilian researchers between 2000 and 2013, only 28.4\% were new. ${ }^{13}$ This probably results from the difficulty in having state-of-art tools for dereplication purposes, which are expensive to purchase and maintain. Aiming to provide a reliable procedure for the identification of known secondary metabolites isolated from fungal culture media, herein we present a practical strategy that enables the rapid identification of natural products by HPLC-UV-LRMS, ${ }^{1} \mathrm{H}$ NMR and, much less often, by ${ }^{13} \mathrm{C}$ NMR. Selected compounds were subsequently evaluated in antiviral bioassays.

\section{EXPERIMENTAL}

\section{General experimental procedures}

Solvents used for extraction and chromatography were of HPLCgrade. Gel permeation chromatography was performed in a glass column $(170.0$ X $2.0 \mathrm{~cm})$ filled with Sephadex LH-20 (Pharmacia Biotech). Flash chromatography was performed using a glass column $(12.0 \times 3.5 \mathrm{~cm})$ filled with silica-gel 200-400 mesh (Sigma Aldrich). Solid-phase extraction was carried out using octadecylsilane, 


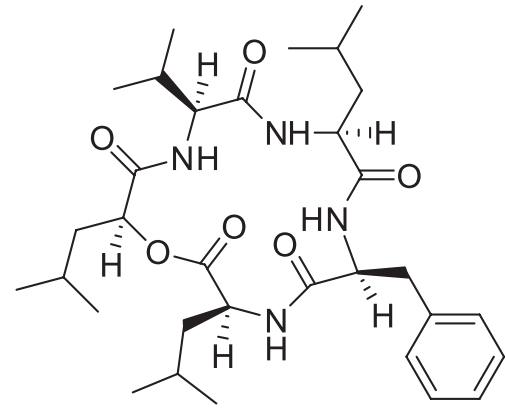

1<smiles>[R]C([R7])[C@H](NC(=O)[C@H](CC(C)C)NC(=O)[C@@H]1C[C@@H]([R2])CN1C(=O)C(C)(C)NC(=O)C(C)(C)C)C(=O)N[C@@H](CCC(N)=O)C(=O)N[C@@H](CO)CC(C)C</smiles>

2. $\mathrm{R}_{1}=\mathrm{Me}, \mathrm{R}_{2}=\mathrm{OH}, \mathrm{n}=12$

3. $\mathrm{R}_{1}=\mathrm{H}, \mathrm{R}_{2}=\mathrm{OH}, \mathrm{n}=12$

4. $R_{1}=M e, R_{2}=H, n=12$

5. $\mathrm{R}_{1}=\mathrm{Me}, \mathrm{R}_{2}=\mathrm{OH}, \mathrm{n}=10$

6. $R_{1}=M e, R_{2}=H, n=10$

Figure 1. Antiviral compounds from marine-derived fungi: sansalvamide A (1) and halovirs A-E (2-6)

cyanopropyl, diol, and silica gel cartridges of different dimensions (Waters and Phenomenex).

HPLC-UV-MS analyses were performed using a Waters Alliance 2695 system coupled on-line with a Waters 2996 photodiode array detector, followed by a Micromass ZQ2000 MS detector with an electrospray interface. The photodiode array detector scanned the samples between $\lambda_{\max } 200$ and $400 \mathrm{~nm}$. The MS detector was optimized to the following conditions- capillary voltage: $3.00 \mathrm{kV}$, source block temperature: $100{ }^{\circ} \mathrm{C}$, desolvation temperature: $350{ }^{\circ} \mathrm{C}$, operating in electrospray positive and negative modes in the detection range between 200 and $800 \mathrm{Da}$ with total ion count extracting acquisition. The cone and desolvation gas flow were 50 and $350 \mathrm{~L} / \mathrm{h}$, respectively, and were generated by a Nitrogen Peak Scientific N110DR nitrogen source. Data acquisition and processing were performed using the Empower 2.0 software. Approximately $1 \mathrm{mg}$ of each sample was diluted in appropriate vials containing $1 \mathrm{~mL}$ of methanol $(\mathrm{MeOH})$. Analyses were performed using different $\mathrm{C}_{18}$ reversed-phase columns: Inertsil ODS-SP, ODS- 3 or C8-4 $(4.6 \times 250 \mathrm{~mm}, 5 \mu \mathrm{m})$, with a gradient of elution of $1: 1(\mathrm{MeOH} / \mathrm{MeCN})$ in $\mathrm{H}_{2} \mathrm{O}+0.1 \%$ formic acid in both organic and aqueous solvents. The gradient of elution started at $10 \%$ to $100 \%$ of the organic mixture, during 22 minutes. The flow rate was $1.0 \mathrm{~mL} \mathrm{~min}^{-1}$.

HPLC semi-preparative purifications were carried out using either a Waters 600 pump in series with a Waters 2487 dual wavelength absorbance detector, or a Waters 2535 quaternary gradient module equipped with a Waters 2489 UV-visible detector. Purifications were performed using analytical/semi-preparative $\mathrm{C}_{18}$ reversed-phase columns Inertsil ODS-SP and/or ODS-3 (4.6 x $250 \mathrm{~mm}, 5 \mu \mathrm{m})$, and $\mathrm{C}_{8}$ columns Inertsil C8-4 and/or InertSustain (4.6 x $250 \mathrm{~mm}, 5 \mu \mathrm{m}$ or 14.0 x $250 \mathrm{~mm}, 5 \mu \mathrm{m})$.

NMR spectra were recorded on a Bruker DRX spectrometer (9.4 T, $400 \mathrm{MHz}$ for ${ }^{1} \mathrm{H}$ ), Bruker AVANCEIII spectrometer $(14.1 \mathrm{~T}, 600 \mathrm{MHz}$ for ${ }^{1} \mathrm{H}$ ) or on an Agilent Technologies 500/54 Premium Shielded spectrometer (11.7 T, $500 \mathrm{MHz}$ for $\left.{ }^{1} \mathrm{H}\right)$. Compounds were dissolved in appropriate deuterated solvents containing tetramethylsilane as internal reference. HRMS analyses were performed using a Bruker Daltonics Ultra-TOF spectrometer or on a LTQ Orbitrap Thermo Scientific spectrometer. Optical rotation analyses were performed using either a Perkin Elmer 241MC polarimeter or a JASCO P2000 polarimeter.

\section{Marine-derived fungal strains obtained from marine invertebrate samples}

Samples of marine invertebrates were collected at Toque-Toque Island, off São Paulo state north coastline, in Brazil. The samples consisted of three marine sponges (Dragmacidon reticulatum, Axinellidae, Ridley \& Dendy, 1886; Mycale laxissima, Mycalidae, Duchassaing \& Michelotti, 1864; and Mycale angulosa, Mycalidae, Duchassaing \& Michelotti, 1864) and one ascidian (Didemnum ligulum, Didemnidae, Monniot, 1983). Vouchers of these marine organisms are deposited at Museu Nacional, Universidade Federal do Rio de Janeiro (sponges) and at Departamento de Zoologia, Setor de Ciências Biológicas, Universidade Federal do Paraná (ascidian). The sponges were identified by Dr. Marcio R. Custódio (Instituto de Biociências, Universidade de São Paulo), while the ascidian was identified by Dra. Rosana M. Rocha (Departamento de Zoologia, Universidade Federal do Paraná).

Fungal strains were isolated as previously reported. ${ }^{14}$ Pure fungal colonies were photographed, morphologically described, subjected to microscopic analysis, and stored at the Grupo de Química Orgânica de Sistemas Biológicos, Departamento de Físico-Química, Instituto de Química de São Carlos. Colonies were identified by conventional and molecular techniques. Identification sequences for each fungal strain can be requested to Dra. Lara Sette (larasette@rc.unesp.br).

\section{An endophytic fungal strain isolated from the leaves of Anthurium loefgrenii}

Samples of leaves from ten plants were collected at Alcatrazes Island, Alcatrazes Archipelago (24ำ' S, 4570' W), off São Paulo state north coastline, in Brazil. Positioning, environment (surroundings) and occurrence data were recorded as well. All samples were collected in sterilized plastic bags and immediately transported to the Universidade de São Paulo Marine Station, CEBIMar/USP. Each plant sample was identified by Dr. Marco Antônio de Assis (Instituto de Biociências, Universidade Estadual Paulista Júlio de Mesquita Filho, UNESP-Rio Claro).

Leaves were cleaned from visible dust and soil with running water and subsequently washed according to a modified Petrini (1991) ${ }^{15}$ protocol, as it follows: the leaves were washed in: 1) sterilized distilled water during $1 \mathrm{~min}, 2) 70 \% \mathrm{EtOH}$ solution during $1 \mathrm{~min}, 3$ ) $\mathrm{HCl} 2.5 \%$ solution during $2 \mathrm{~min}$, 4) $70 \% \mathrm{EtOH}$ solution during $1 \mathrm{~min}$, followed by two washes with sterilized distilled water during $1 \mathrm{~min}$. An aliquot of $100 \mu \mathrm{L}$ from the last wash was plated on PDB culture media in order to confirm the surface sterilization.

For the isolation of endophytic fungi, after surface sterilization leaves were cut with sterilized blades into fragments of approx. 8-12 mm, and three pieces were plated on minimum media + leaves: $\mathrm{K}_{2} \mathrm{HPO}_{4}\left(18.8 \mathrm{~g} \mathrm{~L}^{-1}\right), \mathrm{KH}_{2} \mathrm{PO}_{4}\left(6 \mathrm{~g} \mathrm{~L}^{-1}\right), \mathrm{MgSO}_{4}\left(5 \mathrm{~g} \mathrm{~L}^{-1}\right)$, glycerol (10 $\left.\mathrm{g} \mathrm{L}^{-1}\right)$ and fragments of leaves (added while the media was poured). 
Tetracycline (100 mg L $\left.\mathrm{m}^{-1}\right)$ and streptomycin $\left(20 \mathrm{mg} \mathrm{L}^{-1}\right)$ were added in all media used for inoculation in order to prevent bacterial contamination.

Growth in Petri dishes was performed at $28^{\circ} \mathrm{C}$. After inoculation, the plates were regularly examined in order to verify the growth of filamentous fungi. Pure fungal colonies obtained by successive purification steps were transferred to plates containing MEA (Malt Extract Agar, composition: malt extract $20 \mathrm{~g}$, glucose $20 \mathrm{~g}$, peptone $1 \mathrm{~g}$, agar $20 \mathrm{~g}$ ) medium without antibiotics.

\section{Crude extracts from culture media}

Pure marine-derived fungal strains were first grown in Petri dishes using either $2 \%$ malt (malt extract $20 \mathrm{~g}$, artificial sea water $1 \mathrm{~L}$, agar $15 \mathrm{~g}$ ) or $3 \%$ malt (malt extract $30 \mathrm{~g}$, mycological peptone $3 \mathrm{~g}$, artificial sea water $1 \mathrm{~L}$, agar $15 \mathrm{~g}$ ) culture media. Composition of artificial sea water (ASW) was $1.36 \mathrm{~g}$ of $\mathrm{CaCl}_{2} \cdot \mathrm{H}_{2} \mathrm{O}, 9.68 \mathrm{~g}$ of $\mathrm{MgCl}_{2} \cdot 2 \mathrm{H}_{2} \mathrm{O}$, $0.61 \mathrm{~g}$ of KCl, $30 \mathrm{~g}$ of $\mathrm{NaCl}, 140 \mathrm{mg}$ of $\mathrm{NaH}_{2} \mathrm{PO}_{4}, 3.47 \mathrm{~g}$ of $\mathrm{Na}_{2} \mathrm{SO}_{4}$, $170 \mathrm{mg}$ of $\mathrm{NaHCO}_{3}, 100 \mathrm{mg}$ of $\mathrm{KBr}, 40 \mathrm{mg}$ of $\mathrm{SrCl}_{2} \cdot 6 \mathrm{H}_{2} \mathrm{O}$, and 30 $\mathrm{mg}$ of $\mathrm{HBO}_{3}$ in $1 \mathrm{~L}$ of distilled water. Strains DRG1M2, DLM212, DLM218, F56, and F254 were maintained in 2\% malt, while strains DLM33 and DLM38 were maintained in 3\% malt. The endophytic fungal strain P2AF2F3 was maintained in $2 \%$ malt without ASW. After growth, $2 \mathrm{~mm}$ of mycelia surface samples were obtained using sterilized Pasteur pipettes, and inoculated in $250 \mathrm{~mL}$ of culture media broth of identical formulation to that used for the strains growth on Petri dishes (except for the agar). The strains were grown in static mode for 21 days at room temperature. After growth, an equal volume of ethyl acetate (EtOAc) was added to the cultures, and the mixture of mycelia, culture media, and EtOAc was filtered through a celite bed. The organic phase was separated by liquid-liquid extraction, and subsequently dried under vacuum.

\section{Rapid identification procedure for pure compounds}

Pure compounds were analyzed by HPLC-UV-MS. Data from MS and UV spectra obtained for each compound were used as query for a search on Dictionary of Natural Products. If too many outcomes were returned, another query using organism taxonomic information was made to restrict the search. Since all compounds were isolated from fungal culture media, queries were also performed using the keywords "fungal" or "fungi" or "fungus". If no unambiguous identification was possible at this step, the ${ }^{1} \mathrm{H}$ NMR spectrum of the isolated compound was recorded. Typical ${ }^{1} \mathrm{H}$ signals were used for identification purposes, such as those of singlet or doublet methyl groups, vinylic or benzene hydrogens. In the few instances when organism taxonomical information, UV, LRMS and ${ }^{1} \mathrm{H}$ NMR data did not provide enough information for the unambiguous identification of the pure compound, the ${ }^{13} \mathrm{C}$ NMR spectrum was also recorded and analyzed. No further 2D NMR or HRMS analysis were necessary to identify pure known compounds.

\section{Isolation and identification of fungal secondary metabolites}

Aspergillus sydowii DRG1M2, isolated from the sponge Dragmacidon reticulatum, was inoculated in $8 \mathrm{~L}$ of $2 \%$ malt extract medium (in thirty-two $500 \mathrm{~mL}$ Schott flasks containing $250 \mathrm{~mL}$ of culture medium each). After growth, $250 \mathrm{~mL}$ of EtOAc were added to each Schott flask. This mixture was filtered and the organic phase was separated by liquid-liquid extraction. After evaporation, the EtOAc extract $(2 \mathrm{~g})$ was resuspended in $\mathrm{MeOH}$ and deffated with hexane. The $\mathrm{MeOH}$ extract (1.5 g) was subjected to a gel permeation chromatography using Sephadex LH-20 gel and $\mathrm{MeOH}$ as mobile phase. Six fractions were obtained after analysis by thin layer chromatography (eluent: 9:1 $\mathrm{CH}_{2} \mathrm{Cl}_{2} / \mathrm{MeOH}$; observed under UV light at $\left.\lambda_{\max } 254 \mathrm{~nm}\right)$. Fraction DRG1M2-MC (284.3 mg) presented peaks with UV absorptions at 210-220, 240-250, and 300-310 nm, as well as compounds with molecular weights in the range between 240 and 250 Da by HPLC-UV-MS analysis. This fraction was subjected to a solid-phase extraction on a silica-gel cartridge $(5 \mathrm{~g})$ eluted with 8:2, 7:3, 6:4, 1:1 [1:1 $\left.\left(\mathrm{Hex} / \mathrm{CH}_{2} \mathrm{Cl}_{2}\right)\right] /$ EtOAc], 8:2, 7:3, 6:4, 1:1 $\mathrm{CH}_{2} \mathrm{Cl}_{2} / \mathrm{AcOEt}$, 9:1, 1:1 $\mathrm{CH}_{2} \mathrm{Cl}_{2} / \mathrm{MeOH}$ and $100 \% \mathrm{MeOH}$. From this separation three fraction were obtained. HPLC purification of fraction DRG1M2-MC2 (95.4 mg, column: Inertsil ODS-SP; eluent: 20:20:60 MeOH/MeCN/ $\mathrm{H}_{2} \mathrm{O}+0.1 \%$ formic acid; flow rate of $1.0 \mathrm{~mL} /$ min; detection at $\lambda=254$ and $340 \mathrm{~nm}$ ) led to the isolation of $6.8 \mathrm{mg}$ of sydowic acid (7). ${ }^{16}$ The compound was identified by analysis of spectroscopic data and comparison with literature data. The absolute configuration of (7) was established by comparison of its $[\alpha]_{D}^{23.3}-4$ (c $0.1, \mathrm{MeOH})$ with literature values.

Aspergillus sp. DLM38, isolated from the ascidian Didemnum ligulum, was grown in $4 \mathrm{~L}$ of $3 \%$ malt extract medium (divided in Shott flasks as described above). After liquid-liquid extraction with EtOAc and evaporation of the organic phase, the EtOAc extract $(2.8 \mathrm{~g})$ was subjected to a solid-phase extraction on a cyanopropyl-bonded silica-gel cartridge (10 g) eluted with 9:1, 8:2, 7:3, 6:4, 1:1 $\left[1: 1\left(\mathrm{Hex} / \mathrm{CH}_{2} \mathrm{Cl}_{2}\right)\right] /[1: 1(\mathrm{EtOAc} / \mathrm{MeOH})]$ and $100 \% \mathrm{MeOH}$. Four fractions were obtained after analysis by thin layer chromatography (eluent: 9:1 $\mathrm{CH}_{2} \mathrm{Cl}_{2} / \mathrm{MeOH}$; observed under UV light at $\lambda_{\max } 254 \mathrm{~nm}$ ). Analysis by HPLC-UV-MS indicated that fractions DLM38-A (1.4 g) and DLM38-CE (161.7 mg) presented peaks with UV absorptions at 210-230, 250-290 and 320-330 nm, as well as a compounds with molecular weights in the range between 250 and 600 Da. Fraction DLM38-A was subjected to a solid-phase extraction on a silica-gel cartridge (5 g) eluted with 9:1, 8:2, 7:3, 6:4, 1:1 [75:25 (Hex/ $\left.\left.\mathrm{CH}_{2} \mathrm{Cl}_{2}\right)\right] /[90: 10(\mathrm{EtOAc} / \mathrm{MeOH})], 100 \%$ [90:10 (EtOAc/MeOH)] and $100 \% \mathrm{MeOH}$. After analysis by thin layer chromatography (eluent: 9:1 $\mathrm{CH}_{2} \mathrm{Cl}_{2} / \mathrm{MeOH}$; observed under UV light at $\lambda_{\max } 254$ $\mathrm{nm}$ ), this separation yielded $520.0 \mathrm{mg}$ of DLM38-A1 and $45.5 \mathrm{mg}$ of DLM38-A5. The fraction DLM38-A1 was subjected to a separation by flash chromatography using a glass column filled with silica-gel (200-400 mesh) and eluted with 90:10, 85:15, 80:20, 75:25, 70:30, 65:35, 60:40, 55:45, 50:50 [1:1 $\left.\left(\mathrm{Hex} / \mathrm{CH}_{2} \mathrm{Cl}_{2}\right)\right] /[1: 1: 1$ (EtOAc/ $\mathrm{MeOH} / \mathrm{MeCN})], 100 \%$ [1:1:1 (EtOAc/MeOH/MeCN)], 1:1 MeOH/ $\mathrm{MeCN}$, and $100 \% \mathrm{MeOH}$. This separation yielded four fractions, of which DLM38-A1B (209.4 mg) and DLM38-A1C (59.5 mg) were selected for HPLC purification. The fraction DLM38-A1B was purified by HPLC using a $\mathrm{C}_{8}$ reversed-phase column Inertsil C8-4 with an isocratic elution $\left(60: 40 \mathrm{MeOH} / \mathrm{H}_{2} \mathrm{O}\right)$, at a flow rate of $7.5 \mathrm{~mL} \mathrm{~min}^{-1}$, and detection at $\lambda_{\max } 254 \mathrm{~nm}$. This separation led to the isolation of $6.5 \mathrm{mg}$ of (-)-naphthoquinoneimine (8), identified by analysis of spectroscopic data and comparison with literature data. ${ }^{17}$ The absolute configuration of (8) was established by comparison of its optical rotation value $[\alpha]_{D}{ }^{25}-8(c 3.1, \mathrm{MeOH})$ with literature data. ${ }^{17}$ Purification of the fraction DLM38-A1B6 (51.4 mg, column: Inertsil Ph; eluent: 1:1 [1:1 (MeCN/i-PrOH)/ $\left.\mathrm{H}_{2} \mathrm{O}\right]$, flow rate of 1.0 $\mathrm{mL} / \mathrm{min}$; detection at $\lambda_{\max } 275 \mathrm{~nm}$ ) led to the isolation of $1.3 \mathrm{mg}$ of aurosperone $A(9) .{ }^{18,19}$ Purification of the fraction DLM38-A1C by HPLC (column: Inertsil C8-4; eluent: 60:40 MeOH/ $\mathrm{H}_{2} \mathrm{O}$, flow rate of $7.5 \mathrm{~mL} / \mathrm{min}$, detection at $\lambda_{\max } 310 \mathrm{~nm}$ ) led to the isolation of 8.1 $\mathrm{mg}$ of pyranonigrin $C(\mathbf{1 0})^{20}$ and $9.5 \mathrm{mg}$ of aurosperone $C(\mathbf{1 1}){ }^{19}$ Purification of the fraction DLM38-A5 by HPLC (column: Inertsil ODS-3; isocratic elution: 70:30 [1:1 (MeOH/MeCN)/ $\left.\mathrm{H}_{2} \mathrm{O}\right]$ during 35 minutes, followed by a gradient elution [1:1 (MeOH/MeCN)]/ $\mathrm{H}_{2} \mathrm{O}$ from 50 to $60 \%$ [1:1 (MeOH/MeCN)] in 25 minutes, then an isocratic elution of 100\% 1:1 (MeOH/MeCN) during 5 minutes; flow 
rate: $1.0 \mathrm{~mL} / \mathrm{min}$; detection at $\lambda_{\max } 280 \mathrm{~nm}$ ) led to the isolation of 1.9 mg of pyrophen (12). ${ }^{19,21}$ Purification of the fraction DLM38-CE by HPLC (column: Inertsil ODS-3; gradient elution with 1:1 (MeOH/ $\mathrm{MeCN}) / \mathrm{H}_{2} \mathrm{O}$ from 30 to $42 \%$ [1:1 (MeOH/MeCN) during 20 minutes, then isocratic elution of $100 \%$ [1:1 $(\mathrm{MeOH} / \mathrm{MeCN})$ ] during 6 minutes; flow rate: $1.0 \mathrm{~mL} / \mathrm{min}$; detection at $\lambda=280 \mathrm{~nm}$ ) led to the isolation of $2.0 \mathrm{mg}$ of leucomelone $(\mathbf{1 3})^{22}$ and of $2.1 \mathrm{mg}$ of atromentin $(\mathbf{1 4}) .^{23}$

A second investigation of the strain Aspergillus sp. DLM38 was performed with $10 \mathrm{~L}$ of $3 \%$ malt extract medium. After liquid-liquid extraction with EtOAc and evaporation of the organic phase, the EtOAc extract (4.8 g) was subjected to a solid-phase extraction on a silica-gel cartridge (10 g) eluted with 8:2:0, 6:4:0, 0:1:0, 0:1:1 $\mathrm{CH}_{2} \mathrm{Cl}_{2} /$ $\mathrm{EtOAc} / \mathrm{MeOH}$, and four fractions were obtained. Fraction DLM38-F2 (458.2 $\mathrm{mg}$ ) was subjected to a separation using a $\mathrm{C}_{18}$ reversed-phase silica-gel cartridge $(10 \mathrm{~g})$ eluted with $1: 3,1: 1,3: 1,0: 1 \mathrm{H}_{2} \mathrm{O} / \mathrm{MeOH}$. After HPLC-UV-MS analysis, these fractions were pooled in two fractions DLM38-F2A (78.6 mg) and DLM38-F2B (310.1 mg). DLM38-F2A was separated by HPLC using a $\mathrm{C}_{8}$ reversed-phase column InertSustain $\mathrm{C}_{8}(14.0 \times 250 \mathrm{~mm}, 5 \mu \mathrm{m})$ and isocratic elution of $2: 3 \mathrm{MeOH} / \mathrm{H}_{2} \mathrm{O}$ during 28 minutes, flow rate of $4.0 \mathrm{~mL} / \mathrm{min}$, and detection at $\lambda_{\max } 254$ and $280 \mathrm{~nm}$, to give $1.8 \mathrm{mg}$ of (10) and $8.7 \mathrm{mg}$ of pyranonigin $B(\mathbf{1 5})^{20}$. Fraction DLM38-F2B presented peaks with UV absorptions around 230, 280 and $330 \mathrm{~nm}$, as well as compounds with molecular weights in the range between 575 and $607 \mathrm{Da}$, corresponding to aurosperones derivatives previously isolated, so this fraction was ignored.

Penicillium glabrum DLM218, isolated from the ascidian Didemnum ligulum, was grown in $8 \mathrm{~L}$ of $2 \%$ malt extract medium (in Shott flasks, as described above). After liquid-liquid extraction with EtOAc and evaporation of the organic phase, the EtOAc extract (2.9 g) was subjected to a solid-phase extraction on a $\mathrm{C}_{18}$ reversed-phase silica-gel cartridge (10 g) eluted with 15:85, 30:70, 50:50, 70:30, $85: 15 \mathrm{MeOH} / \mathrm{H}_{2} \mathrm{O}$ and $100 \% \mathrm{MeOH}$. Analysis by HPLC-UV-MS of the fractions DLM218-ABC (1.19 g) and DLM218-E (470.7 mg) showed peaks with UV absorptions at $\lambda_{\max } 220-230,250-270,280-300$ and $385 \mathrm{~nm}$, and compounds with molecular weights in the range between 270 and 390 Da. Fraction DLM218-ABC was separated by HPLC using a $\mathrm{C}_{8}$ reversed-phase column Inertsil C8-4 and gradient elution from $20 \% \mathrm{MeOH} / \mathrm{H}_{2} \mathrm{O}$ to $100 \% \mathrm{MeOH}$ during 55 minutes, flow rate of $8.0 \mathrm{~mL} / \mathrm{min}$, and detection at $\lambda_{\max } 280$ and $300 \mathrm{~nm}$. HPLC-UV-MS analysis of the fraction DLM218-ABC7 $(65.1 \mathrm{mg})$ indicated a major peak with $\lambda_{\max } 283,307$, and $383 \mathrm{~nm}$ in the UV spectrum, a peak with $\mathrm{m} / \mathrm{z} 381.2$ in the mass spectrum corresponding to the $[\mathrm{M}+\mathrm{H}]^{+}$ion, and a peak with $\mathrm{m} / \mathrm{z} 379.3$ corresponding to the $[\mathrm{M}-\mathrm{H}]$ ] ion of compound (15). HPLC purification (column: Inertsil C8-4; isocratic elution: $64: 36 \mathrm{MeOH} / \mathrm{H}_{2} \mathrm{O}$; flow rate of $7.0 \mathrm{~mL} / \mathrm{min}$; detection at $\lambda_{\max } 280$ and $300 \mathrm{~nm}$ ) of the major compound led to the isolation of $5.7 \mathrm{mg}$ of penicitrinone A (16).$^{24}$ Fraction DLM218-E $\left(88.9 \mathrm{mg}\right.$ ) was separated by HPLC using a $\mathrm{C}_{8}$ reversed-phase column Inertsil C8-4 (isocratic elution with $58: 42 \mathrm{MeOH} / \mathrm{H}_{2} \mathrm{O}$; flow rate of 7.0 $\mathrm{mL} / \mathrm{min}$; detection at $\lambda_{\max } 275$ and $310 \mathrm{~nm}$ ). HPLC-UV-MS analysis of the fraction DLM218-E4 (88.9 mg) indicated a major peak with $\lambda_{\max }$ 235, 263, 295 and $384 \mathrm{~nm}$ in the UV spectrum, a peak with $\mathrm{m} / z, 299.3$ in the mass spectrum corresponding to the $[\mathrm{M}+\mathrm{H}]^{-}$ion, and a peak with $\mathrm{m} / \mathrm{z} 323.1$ corresponding to the $[\mathrm{M}+\mathrm{Na}]^{+}$ion of compound (17). HPLC purification of (17) (column: Inertsil C8-4; isocratic elution: 59:41 MeOH/ $\mathrm{H}_{2} \mathrm{O}$, flow rate of $7.0 \mathrm{~mL} / \mathrm{min}$, detection at $\lambda_{\max } 254$ and $280 \mathrm{~nm}$ ) led to the isolation of $5.2 \mathrm{mg}$ of pinselin (17). ${ }^{25} \mathrm{HPLC}$ UV-MS analysis of the fraction DLM218-E6 (217.4 mg) indicated two major peaks with $\lambda_{\max } 283,307,383$, and 221, 266, $287 \mathrm{~nm}$ in the UV spectrum, with $\mathrm{m} / \mathrm{z} 381.1$ and 271.2 in the mass spectrum, corresponding to the $[\mathrm{M}+\mathrm{H}]^{+}$ions of (15) and (18), respectively. HPLC purification of (15) and (18) (column: Inertsil C8-4; isocratic elution: 49:51 MeCN/ $\mathrm{H}_{2} \mathrm{O}$; flow rate of $7.0 \mathrm{~mL} \mathrm{~min}^{-1}$; detection at $\lambda_{\max } 254$ and $280 \mathrm{~nm}$ ) led to the isolation of $13.3 \mathrm{mg}$ of (15) and $9.4 \mathrm{mg}$ of emodin $(\mathbf{1 8}){ }^{26}$

Penicillium citrinum DLM212, isolated from the ascidian Didemnum ligulum, was grown in $8 \mathrm{~L}$ of $2 \%$ malt extract medium (in Shott flasks as described above). After liquid-liquid extraction with EtOAc and evaporation of the organic phase, the EtOAc extract (2 g) was resuspended in $\mathrm{MeOH}$ and deffated with hexane. The $\mathrm{MeOH}$ fraction $(1.5 \mathrm{~g})$ was subjected to a gel permeation chromatography using a glass column filled with Sephadex LH-20 gel and MeOH as mobile phase. Six fractions were obtained after analysis by thin layer chromatography (eluent: 9:1 $\mathrm{CH}_{2} \mathrm{Cl}_{2} / \mathrm{MeOH}$; observed under UV light at $\lambda_{\max } 254 \mathrm{~nm}$ ), of which DLM212-MB (122.4 mg), DLM212-MC $(551.5 \mathrm{mg})$ and DLM212-ME $(66.8 \mathrm{mg})$ presented peaks with UV absorptions at $\lambda_{\max } 210-230,250-290$, and $315 \mathrm{~nm}$, in the mass range between 250 and 300 Da by HPLC-UV-MS analysis. The fraction DLM212-MB was separated by HPLC using a $\mathrm{C}_{18}$ reversed-phase column Inertsil ODS-SP (isocratic elution with 35:35:30 MeOH/ $\mathrm{MeCN} / \mathrm{H}_{2} \mathrm{O}+0.1 \%$ formic acid; flow rate of $1.0 \mathrm{~mL} / \mathrm{min}$; detection at $\lambda_{\max } 270$ and $\left.340 \mathrm{~nm}\right)$. HPLC purification of the fraction DLM212MB2 (35.0 mg) (column: Inertsil ODS-SP; isocratic elution: 25:25:50 $\mathrm{MeOH} / \mathrm{MeCN} / \mathrm{H}_{2} \mathrm{O}+0.1 \%$ formic acid; flow rate of $1.0 \mathrm{~mL} / \mathrm{min}$; detection at $\lambda_{\max } 270$ and $340 \mathrm{~nm}$ ) led to the isolation of $1.0 \mathrm{mg}$ of quinolactacin $B$ (19). ${ }^{27}$ HPLC-UV-MS analysis of the fraction DLM212-MB4 $(9.0 \mathrm{mg})$ indicated a major peak with $\lambda_{\max } 224$ and $283 \mathrm{~nm}$ in the UV spectrum, and a peak with $\mathrm{m} / \mathrm{z}, 298.3$ in the mass spectrum, corresponding to the $[\mathrm{M}+\mathrm{H}]^{+}$ion of $(\mathbf{2 0})$. Purification of (20) by HPLC (column: Inertsil ODS-SP; isocratic elution: 35:35:30 $\mathrm{MeOH} / \mathrm{MeCN} / \mathrm{H}_{2} \mathrm{O}+0.1 \%$ formic acid; flow rate of $1.0 \mathrm{~mL} / \mathrm{min}$; detection at $\lambda_{\max } 254$ and $270 \mathrm{~nm}$ ) led to the isolation of $2.3 \mathrm{mg}$ of penicillenol A (20). ${ }^{28}$ Purification of the fraction DLM212-ME (66.8 $\mathrm{mg}$ ) by HPLC (column: Inertsil ODS-SP; isocratic elution: 35:35:30 MeOH/MeCN/ $\mathrm{H}_{2} \mathrm{O}+0.1 \%$ formic acid; flow rate of 1.0 $\mathrm{mL} / \mathrm{min}$; detection at $\lambda_{\max } 270$ and $340 \mathrm{~nm}$ ) led to the isolation of 14.7 $\mathrm{mg}$ of citreorosein (21) ${ }^{29}$ and $15.4 \mathrm{mg}$ of (18). Fraction DLM212-MC was subjected to a solid-phase extraction on a cyanopropyl-bonded silica-gel cartridge ( $10 \mathrm{~g}$ ) eluted with 8:2, 7:3, 6:4, 1:1 $\mathrm{CH}_{2} \mathrm{Cl}_{2} / \mathrm{EtOAc}$, $100 \%$ EtOAc, 1:1 EtOAc/MeOH and $100 \% \mathrm{MeOH}$. HPLC purification of DLM212-MC2 (83.7 mg, column: Inertsil ODS-SP; isocratic elution: $15: 15: 70 \mathrm{MeOH} / \mathrm{MeCN} / \mathrm{H}_{2} \mathrm{O}+0.1 \%$ formic acid; flow rate of $1.0 \mathrm{~mL} / \mathrm{min}$; detection at $\lambda_{\max } 254$ and $280 \mathrm{~nm}$ ) yielded $2.0 \mathrm{mg}$ of DLM212-MC2E. HPLC-UV-MS analysis of this fraction indicated a major peak with $\lambda_{\max } 218,250$ and $316 \mathrm{~nm}$ in the UV spectrum, and a peak with $\mathrm{m} / \mathrm{z} 287.0$ in the mass spectrum, corresponding to the $[\mathrm{M}+\mathrm{H}]^{+}$ion of the quinolactacin $C(\mathbf{2 2}) .^{27}$

Roussoella sp. DLM33, isolated from the ascidian Didemnum ligulum, was grown in $10 \mathrm{~L}$ of $3 \%$ malt extract medium (as described above). After liquid-liquid extraction of the growth medium with EtOAc and evaporation of the organic phase, the EtOAc extract (1.78 g) was separated by gel permeation chromatography using Sephadex LH-20 gel and $\mathrm{MeOH}$ as mobile phase. After analysis by thin layer chromatography (eluent: 9:1 $\mathrm{CH}_{2} \mathrm{Cl}_{2} / \mathrm{MeOH}$; observed under UV light at $\lambda_{\max } 254 \mathrm{~nm}$ ) four fractions were obtained, of which DLM33-A7 (141.5 mg) gave a precipitate (DLM33-A7-ppt $=16.9$ $\mathrm{mg}$ ). Chromatographic separation of this solid on a silica-gel cartridge yielded $9.5 \mathrm{mg}$ of 5-methylmellein (23). ${ }^{30}$ The absolute configuration of (23) was established by comparison of its $[\alpha]_{\mathrm{D}}^{25}-81$ (c 1.24, $\mathrm{MeOH})$ with literature data. ${ }^{30}$ Fraction DLM33-A7 was subjected to a chromatographic separation on a silica gel cartridge $(5 \mathrm{~g})$ eluted with 9:1 [1:9 (Hex: $\left.\left.\mathrm{CH}_{2} \mathrm{Cl}_{2}\right)\right] /[95: 5$ (EtOAc:MeOH)]. This separation yielded $42.1 \mathrm{mg}$ of DLM33-A7A19. Fraction DLM33-A7A19 was separated by HPLC using a $\mathrm{C}_{18}$ reversed-phase column Inertsil ODS-SP (gradient of elution from $10 \% \mathrm{MeOH} / \mathrm{H}_{2} \mathrm{O}$ to $50 \% \mathrm{MeOH}$ 
during 25 minutes; flow rate of $1.0 \mathrm{~mL} / \mathrm{min}$; detection at $\lambda_{\max } 254$ and $280 \mathrm{~nm}$ ). HPLC purification of the fraction DLM33-A7A19M (21.2 mg) (column: Inertsil C8-4; isocratic elution: 46:54 MeOH/ $\mathrm{H}_{2} \mathrm{O}$; flow rate of $1.0 \mathrm{~mL} / \mathrm{min}$; detection at $\lambda_{\max } 254$ and $280 \mathrm{~nm}$ ) led to the isolation of $1.0 \mathrm{mg}$ of 5,7-dichloro-3-methyl-6-methoxy8-hydroxy-3,4-dihydroisocoumarin (24). ${ }^{31}$

Cochliobolus sp. F56, isolated from the sponge Mycale laxissima, was grown in $2 \mathrm{~L}$ of $2 \%$ malt extract medium (in ten $500 \mathrm{~mL}$ Schott flasks containing $200 \mathrm{~mL}$ of medium each). After liquidliquid extraction of the growth medium with EtOAc and evaporation of the organic phase, the EtOAc extract (407.2 mg) was subjected to a separation by gel permeation chromatography using Sephadex LH$20 \mathrm{gel}$ and $\mathrm{MeOH}$ as mobile phase. Five fractions were obtained after analysis by thin layer chromatography (eluent: 9:1 $\mathrm{CH}_{2} \mathrm{Cl}_{2} / \mathrm{MeOH}$; observed under UV light at $\lambda_{\max } 254 \mathrm{~nm}$ ), of which F56-A2 (141.5 $\mathrm{mg}$ ) and F56-A4 (17.4 mg) were chosen for purification procedures. The fraction F56-A2 was subjected to a solid-phase extraction on a diol-bonded silica-gel cartridge (5 g) eluted with 6:4 [1:1 (Hex/ $\mathrm{CH}_{2} \mathrm{Cl}_{2}$ )]/EtOAc, $100 \%$ EtOAc, $1: 1 \mathrm{EtOAc} / \mathrm{MeOH}$ and $100 \%$ $\mathrm{MeOH}$. HPLC-UV-MS analysis of the fraction F56-A2(4) (32.9 $\mathrm{mg}$ ) indicated a major peak with $\lambda_{\max } 261 \mathrm{~nm}$ in the UV spectrum, and a peak with $\mathrm{m} / \mathrm{z} 287.3$ in the mass spectrum, corresponding to the $[\mathrm{M}+\mathrm{H}]^{+}$ion of $\mathbf{2 5}$. HPLC purification of (25) (column: Inertsil ODS-SP; isocratic elution: 21:21:58 MeOH/MeCN/ $\mathrm{H}_{2} \mathrm{O}+0.1 \%$ formic acid; flow rate of $1.0 \mathrm{~mL} / \mathrm{min}$; detection at $\lambda_{\max } 230$ and $254 \mathrm{~nm}$ ) led to the isolation of $4.0 \mathrm{mg}$ of (+)-abscisic acid (25). ${ }^{32}$ The absolute configuration of $\mathbf{2 5}$ was established by comparison of its $[\alpha]_{\mathrm{D}}{ }^{25}+87(c 2.0, \mathrm{MeOH})$ with literature data. Fraction F56-A4 was separated by HPLC using a reversed-phase $\mathrm{C}_{18}$ column Inertsil ODS-SP (isocratic elution with 24:24:52 MeOH/MeCN/ $\mathrm{H}_{2} \mathrm{O}+0.1 \%$ formic acid; flow rate of $1.0 \mathrm{~mL} / \mathrm{min}$; detection at $\lambda=230$ and 320 $\mathrm{nm})$. This separation led to the isolation of $2.2 \mathrm{mg}$ of 4-hydroxy3-(3-methylbut-2-enyl)benzoic acid (26) ${ }^{33}$ and of $1.0 \mathrm{mg}$ of anofinic acid (27). ${ }^{33}$ HPLC-UV-MS analysis of fraction F56-A4(2) indicated a major peak with $\lambda_{\max } 240,279$ and $347 \mathrm{~nm}$ in the UV spectrum, and a peak with $\mathrm{m} / \mathrm{z} 209.07$ in the mass spectrum, corresponding to the $[\mathrm{M}+\mathrm{H}]^{+}$ion of (28). Purification by HPLC (column: Inertsil ODS-SP; isocratic elution with 20:20:60 MeOH/MeCN/ $\mathrm{H}_{2} \mathrm{O}+$ $0.1 \%$ formic acid; flow rate of $1.0 \mathrm{~mL} / \mathrm{min}$; detection at $\lambda_{\max } 230$ and $320 \mathrm{~nm}$ ) of the major compound led to the isolation of $0.8 \mathrm{mg}$ of 2,3-dihydro-6,7-dihydroxy-2,2-dimethylchromen-4-one (28).

Trichoderma sp. F254, isolated from the sponge Mycale laxissi$m a$, was grown in $2 \mathrm{~L}$ of $2 \%$ malt extract medium (as for Cochliobolus $s p$. F56). After liquid-liquid extraction with EtOAc and evaporation of the organic phase, the EtOAc extract $(241.6 \mathrm{mg}$ ) was separated by gel permeation chromatography using Sephadex LH-20 gel and $\mathrm{MeOH}$ as mobile phase. After analysis by thin layer chromatography (eluent: 9:1 $\mathrm{CH}_{2} \mathrm{Cl}_{2} / \mathrm{MeOH}$; observed under UV light at $\lambda_{\max } 254 \mathrm{~nm}$ ) six fractions were obtained, of which F254-E (59.9 mg) was purified by HPLC (column: Inertsil ODS-SP; gradient elution: [1:1 (MeOH/ $\mathrm{MeCN})] / \mathrm{H}_{2} \mathrm{O}+0.1 \%$ formic acid from 20 to $80 \%$ [1:1 (MeOH/ $\mathrm{MeCN})$ ] during 30 minutes, then from 80 to $100 \% 1: 1(\mathrm{MeOH} /$ $\mathrm{MeCN})$ during 1 minute and isocratic elution at 100\% 1:1 (MeOH/ $\mathrm{MeCN}$ ) during 4 minutes; flow rate of $1.0 \mathrm{~mL} / \mathrm{min}$; detection at $\lambda_{\max }$ 254 and $280 \mathrm{~nm}$ ). This procedure led to the isolation of $5.9 \mathrm{mg}$ of harzianopyridone (29). ${ }^{34}$

Penicillium paxilli $\mathrm{Ma}(\mathrm{G}) \mathrm{K}$, isolated from the sponge Mycale angulosa, was grown $2 \mathrm{~L}$ of $2 \%$ malt medium (as for Cochliobolus $s p$. F56). The culture was incubated in a rotary shaker (100 rpm) at $25{ }^{\circ} \mathrm{C}$ for seven days. At the end of the growth period, $200 \mathrm{~mL}$ of EtOAc were added to each Schott flask. The mixture was shaken at $100 \mathrm{rpm}$ for $24 \mathrm{~h}$ at $25^{\circ} \mathrm{C}$, filtered through a celite bed and the organic phase was separated by liquid-liquid extraction. After evaporation, the
EtOAc extract ( $400 \mathrm{mg}$ ) was subjected to a solid-phase extraction on a cyanopropyl-bonded silica-gel cartridge ( $2 \mathrm{~g}$ ), eluted with $100 \% \mathrm{CH}_{2} \mathrm{Cl}_{2}$ (fraction $\mathrm{Ma}(\mathrm{G}) \mathrm{K}-\mathrm{A}, 130.0 \mathrm{mg}$ ), 100\% EtOAc (fraction $\mathrm{Ma}(\mathrm{G}) \mathrm{K}-\mathrm{B}$, $68.2 \mathrm{mg}$ ), and finally eluted with $100 \% \mathrm{MeOH}$ (fraction $\mathrm{Ma}(\mathrm{G}) \mathrm{K}-\mathrm{C}$, $155.0 \mathrm{mg}$ ). Fraction $\mathrm{Ma}(\mathrm{G}) \mathrm{K}-\mathrm{A}$ was separated by HPLC using a $\mathrm{C}_{18}$ reversed-phase column Inertsil ODS-3 $(4.6 \times 250 \mathrm{~mm} ; 5 \mu \mathrm{m})$ (isocratic elution with $1: 1 \mathrm{MeOH} / \mathrm{MeCN}$ in $\mathrm{H}_{2} \mathrm{O}+0.1 \%$ formic acid), flow rate of $1.0 \mathrm{~mL} / \mathrm{min}$, and detection at $\lambda_{\max } 254 \mathrm{~nm}$. This separation yielded $42.7 \mathrm{mg}$ of pyrenocine $A(\mathbf{3 0})^{14,35}$ and $6.0 \mathrm{mg}$ of pyrenocine $B(\mathbf{3 1}) .^{14,35}$

The yet unidentified fungal strain P2AF2F3, isolated from the plant Anthurium loefgrenii, was inoculated in $10 \mathrm{~L}$ of $2 \%$ malt extract medium (in thirty-two $500 \mathrm{~mL}$ Schott flasks containing 250 $\mathrm{mL}$ of media each). After liquid-liquid extraction with EtOAc and evaporation of the organic phase, the EtOAc extract (900 mg) was resuspended in $\mathrm{MeOH}$ and deffated with hexane. The $\mathrm{MeOH}$ extract was subjected to a gel permeation chromatography using Sephadex LH-20 gel and MeOH as mobile phase. Five fractions were obtained. The fraction P2AF2F3-3 (530 mg) was subjected to a solid-phase extraction on a diol cartridge (10 g) eluted with 9:1, 8:2, 7:3, 6:4 [(1:9 $\left.\left.\mathrm{Hex} / \mathrm{CH}_{2} \mathrm{Cl}_{2}\right) /(1: 9 \mathrm{EtOAc} / \mathrm{MeOH})\right]$ and $100 \%$ (1:9 EtOAc/MeOH). From this separation five others fractions were obtained. Fraction P2AF2F3-3A (200 mg) was subjected to a solid-phase extraction on a $\mathrm{C}_{18}$ cartridge $\left(10 \mathrm{~g}\right.$ ) eluted with $3: 7$ and $6: 4 \mathrm{MeOH} / \mathrm{H}_{2} \mathrm{O}$, then $100 \% \mathrm{MeOH}$. Fraction P2AF2F3-3A2 (154 mg) presented peaks with UV absorptions at 220-240 nm, in the mass range between 240 and 280 Da by HPLC-UV-MS analysis. HPLC purification of fraction P2AF2F3-3A2 (column: IntertSustain $\mathrm{C}_{8}$; eluent: 1:1:3 MeOH/ $\mathrm{MeCN} / \mathrm{H}_{2} \mathrm{O}$; flow rate of $1.0 \mathrm{~mL} / \mathrm{min}$; detection at $\lambda_{\max } 255$ and 215 $\mathrm{nm}$ ) led to the isolation of $3.2 \mathrm{mg}$ of conocenol B (32). ${ }^{36}$

\section{Spectroscopic data of pure compounds isolated from fungal strains}

Sydowic acid (7): yellow oil. UV $\left(\lambda_{\max } \mathrm{nm}\right): 212,244,299 .{ }^{1} \mathrm{H}$ NMR (400 MHz, TMS, DMSO- $d_{6}$ ): $\delta$ (ppm); 0.97 (3H, s, H3-12), 0.98 (3H, s, H3-13), 1.06 (1H, m, H-9 $\left.{ }_{\mathrm{A}}\right), 1.25$ (2H, m, H2-10), 1.30 $\left(1 \mathrm{H}, \mathrm{m}, \mathrm{H}-9_{\mathrm{B}}\right), 1.50(3 \mathrm{H}, \mathrm{s}, \mathrm{H} 3-14), 1.66\left(1 \mathrm{H}, \mathrm{m}, \mathrm{H}-8_{\mathrm{A}}\right), 1.92(1 \mathrm{H}, \mathrm{m}$, H- $\left.8_{\mathrm{B}}\right), 5.55(1 \mathrm{H}, \mathrm{s}, \mathrm{OH}-1), 7.28(1 \mathrm{H}, \mathrm{d}, J=1.7 \mathrm{~Hz}, \mathrm{H}-2), 7.33(1 \mathrm{H}$, dd, $J=8.0,1.7 \mathrm{~Hz}, \mathrm{H}-4), 7.39(1 \mathrm{H}, \mathrm{d}, J=8.0 \mathrm{~Hz}, \mathrm{H}-5), 9.98(1 \mathrm{H} \mathrm{s}$, $\mathrm{OH}-15) .{ }^{13} \mathrm{C}$ NMR (100 MHz, TMS, DMSO- $d_{6}$ ): $\delta(\mathrm{ppm}) ; 18.7$ (C-9), 28.4 (C-14), 29.4 (C-13), 29.5 (C-12), 42.1 (C-8), 44.2 (C-10), 68.9 (C-11), 75.0 (C-7), 116.8 (C-2), 119.9 (C-5), 127.1 (C-4), 130.3 (C-3), 138.1 (C-6), 154.8 (C-1), $167.4(\mathrm{C}-15)$. ESI ${ }^{+}-\mathrm{MS}: \mathrm{m} / \mathrm{z} 247\left[\mathrm{M}-\mathrm{H}_{2} \mathrm{O}\right]^{+}$ (calcd for $\mathrm{C}_{15} \mathrm{H}_{19} \mathrm{O}_{3}, 247.13342$ ). $[\alpha]_{\mathrm{D}}^{23.3}-4$ (c 0.1, MeOH).

(-)-Naphthoquinoneimine $(8)$ : red amorphous solid. UV $\left(\lambda_{\max } \mathrm{nm}\right)$ : 207, 270, 334. ${ }^{1} \mathrm{H}$ NMR (400 MHz, TMS, MeCN- $d_{3}$,): $\delta$ (ppm); 3.22 ( $\left.1 \mathrm{H}, \mathrm{dd}, J=13.9,8.2 \mathrm{~Hz}, \mathrm{H}-8_{\mathrm{A}}{ }^{\prime}\right), 3.31$ ( $\left.1 \mathrm{H}, \mathrm{dd}, J=13.9,6.0 \mathrm{~Hz}, \mathrm{H}-8_{\mathrm{B}}{ }^{\prime}\right)$, 3.77 (3H, s, H3-9'), 4.51 (1H, ddd, $J=8.2,8.0,6.0 \mathrm{~Hz}, \mathrm{H}-7$ '), $5.46(1 \mathrm{H}$, d, J=2.3 Hz, H-5'), 5.51 (1H, s, H-3), 5.99 (1H, d, J=2.3 Hz, H-3'), 6.39 (1H, d, J=8.0 Hz, NH-10'), 6.51 (1H, d, J=2.4 Hz, H-8), 6.96 (1H, d, J=2.4 Hz, H-6), 7.28 (5H, m, H-2', H-3', H-4', H-5', H-6'), $12.91(1 \mathrm{H}, \mathrm{s}, 0 \mathrm{H}-5) .{ }^{13} \mathrm{C} \mathrm{NMR}\left(100 \mathrm{MHz}, \mathrm{TMS}, \mathrm{MeCN}-d_{3},\right): \delta(\mathrm{ppm})$; 38.3 (C-8'), 55.7 (C-7'), 56.2 (C-9'), 88.3 (C-5'), 100.4 (C-3'), 101.2 (C-3), 107.9 (C-4a), 108.9 (C-6), 117.3 (C-8), 127.1 (C-4”), 128.6 (C-3", C-5"), 129.2 (C-2", C-6"), 132.2 (C-8a), 136.3 (C-1"), 147.5 (C-2), 161.0 (C-2'), 163.2 (C-5), 163.3 (C-7), 163.4 (C-6'), 170.8 (C-4'), 180.7 (C-1), 188.4 (C-4). ESI ${ }^{+}-$HRMS: m/z $434.1235[\mathrm{M}+\mathrm{H}]^{+}$ (calcd for $\left.\mathrm{C}_{24} \mathrm{H}_{20} \mathrm{NO}_{7}, 434.1\right)$. [ $\left.\alpha\right]_{\mathrm{D}}{ }^{25}-8$ (c 3.1, MeOH).

Aurosperone A (9): yellow solid. UV $\left(\lambda_{\max } \mathrm{nm}\right): 228,258,277 .{ }^{1} \mathrm{H}$ NMR see refs. 18 and 19. ESI ${ }^{+}-\mathrm{MS}: m / z 571.1[\mathrm{M}+\mathrm{H}]^{+}$(calcd for $\mathrm{C}_{32} \mathrm{H}_{27} \mathrm{O}_{10}$, 571.2).

Pyranonigrin $C(\mathbf{1 0})$ : amorphous solid. UV $\left(\lambda_{\max } \mathrm{nm}\right): 231$, 290, 329. ${ }^{1} \mathrm{H}$ NMR see ref. 20. ESI+-MS: $m / z, 254.4[\mathrm{M}+\mathrm{H}]^{+}$(calcd 
for $\left.\mathrm{C}_{11} \mathrm{H}_{12} \mathrm{NO}_{6}, 254.1\right)$, $\mathrm{ESI}^{+}-\mathrm{MS}: \mathrm{m} / z, 529.2[2 \mathrm{M}+\mathrm{Na}]^{+}$(calcd for $\mathrm{C}_{22} \mathrm{H}_{22} \mathrm{~N}_{2} \mathrm{NaO}_{12}, 529.1$ ).

Aurosperone $C$ (11): amorphous solid. UV $\left(\lambda_{\max } \mathrm{nm}\right): 233,282$, 334. ${ }^{1} \mathrm{H}$ NMR (400 MHz, TMS, MeCN- $d_{3}$ ) : $\delta(\mathrm{ppm}) ; 1.44(3 \mathrm{H}, \mathrm{s}$, H3-11'), 1.68 (3H, s, H3-2), 2.83 (2H, d, $J=16.5$ Hz, H2-3'), 3.09 (2H, d, J=16.5 Hz, H2-3), 3.49 (3H, s, H3-12), 3.59 (3H, s, H3-13'), 3.92 (3H, s, H3-12'), 6.13 (1H, s, H-7'), 6.40 (1H, s, H-9'), 6.59 (1H, s, H-9), $6.92(1 \mathrm{H}, \mathrm{s}, \mathrm{H}-10)$. ESI ${ }^{+}-\mathrm{MS}: \mathrm{m} / z, 593.1[\mathrm{M}+\mathrm{H}]^{+}$(calcd for $\mathrm{C}_{31} \mathrm{H}_{29} \mathrm{O}_{12}$, 593.2).

Pyrophen (12): yellow crystal. UV ( $\left.\lambda_{\max } \mathrm{nm}\right): 265 .{ }^{1} \mathrm{H}$ NMR (400 MHz, TMS, DMSO- $\left.d_{6}\right): \delta(\mathrm{ppm}) ; 1.78(3 \mathrm{H}, \mathrm{s}, \mathrm{H} 3-15), 2.89(1 \mathrm{H}, \mathrm{dd}$, $\left.J=13.7,8.2 \mathrm{~Hz}, \mathrm{H}-7_{\mathrm{A}}\right), 3.02\left(1 \mathrm{H}, \mathrm{dd}, J=13.7,8.2 \mathrm{~Hz}, \mathrm{H}-7_{\mathrm{B}}\right), 3.78(3 \mathrm{H}$, s, H3-16), 4.76 (1H, q, J=8.2 Hz, H-6), 5.57 (1H, d, $J=2.1 \mathrm{~Hz}, \mathrm{H}-2)$, $6.05(1 \mathrm{H}, \mathrm{d}, J=2.1 \mathrm{~Hz}, \mathrm{H}-4), 7.19$ (2H, m, H-9, H-13), $7.21(1 \mathrm{H}, \mathrm{m}$, $\mathrm{H}-11), 7.27$ (2H, m, H-10, H-12 ), $8.46(1 \mathrm{H}, \mathrm{d}, J=8.2 \mathrm{~Hz}, \mathrm{NH}-6) .{ }^{13} \mathrm{C}$ NMR (100 MHz, TMS, DMSO- $d_{6}$ ): $\delta$ (ppm); 22.8 (C-15), 39.0 (C-7), 52.5 (C-6), 56.9 (C-16), 88.4 (C-2), 99.8 (C-4), 127.2 (C-11), 128.7 (C-10, C-12), 129.4 (C-9, C-13), 137.0 (C-8), 163.8 (C-5), 164.2 (C-1), 169.0 (C-14), 170.0 (C-3). ESI-MS: m/z 323.2 [M+Cl] ${ }^{-}$(calcd for $\left.\mathrm{C}_{16} \mathrm{H}_{17} \mathrm{ClNO}_{4}, 322.1\right)$. $[\alpha]_{\mathrm{D}}^{25} 0$ (c $\left.0.7, \mathrm{MeOH}\right)$.

Leucomelone (13): amorphous solid. UV $\left(\lambda_{\max } \mathrm{nm}\right): 265 .{ }^{1} \mathrm{H}$ NMR (400 MHz, TMS, DMSO- $\left.d_{6}\right)$ ): $\delta(\mathrm{ppm}) ; 6.67(1 \mathrm{H}, \mathrm{d}, J=8.2$ Hz, H-5'), 6.70 (2H, d, J=8.4 Hz, H-3", H-5”), 6.75 (1H, dd, J=8.2, $2.1 \mathrm{~Hz}, \mathrm{H}-6$ '), 6.90 (1H, d, J=2.1 Hz, H-2'), 7.29 (2H, d, J=8.4 Hz, H-2", H-6"). ESI-MS: $m / z, 339.2$ [M-H]' (calcd for $\mathrm{C}_{18} \mathrm{H}_{11} \mathrm{O}$ 7, 339.1).

Atromentin (14): amorphous solid. UV $\left(\lambda_{\max } \mathrm{nm}\right): 266 .{ }^{1} \mathrm{H}$ NMR (400 MHz, TMS, DMSO- $d_{6}$,): $\delta$ (ppm); 6.74 (1H, d, $J=8.6$ Hz, H-3'), $7.24\left(1 \mathrm{H}, \mathrm{d}, J=8.6 \mathrm{~Hz}, \mathrm{H}-2^{\prime}\right)$. ESI-MS: $m / z, 323.2[\mathrm{M}-\mathrm{H}]^{-}$(calcd for $\mathrm{C}_{18} \mathrm{H}_{11} \mathrm{O}$ 6, 323.1).

Pyranonigrin $B(\mathbf{1 5})$ : amorphous solid. UV $\left(\lambda_{\max } \mathrm{nm}\right): 233$, 291, 371. ${ }^{1} \mathrm{H}$ NMR see ref. 20. ESI ${ }^{+}-\mathrm{MS}: \mathrm{m} / z, 254.4[\mathrm{M}+\mathrm{H}]^{+}$(calcd for $\mathrm{C}_{11} \mathrm{H}_{12} \mathrm{NO}_{6}, 254.1$ ), ESI+-MS: $m / z, 237.1\left[\mathrm{M}-\mathrm{H}_{2} \mathrm{O}\right]^{+}$(calcd for $\left.\mathrm{C}_{11} \mathrm{H}_{11} \mathrm{NO}_{5}, 237.0\right)$.

Penicitrinone A (16): amorphous solid. UV $\left(\lambda_{\max } \mathrm{nm}\right): 283,307$, 383. ${ }^{1} \mathrm{H}$ NMR (400 MHz, TMS, DMSO- $\left.d_{6}\right): \delta(\mathrm{ppm}) ; 1.28(3 \mathrm{H}, \mathrm{d}$, $J=7.0 \mathrm{~Hz}, \mathrm{H} 3-10), 1.30$ (3H, d, $\left.J=6.8 \mathrm{~Hz}, \mathrm{H} 3-9^{\prime}\right), 1.34$ (6H, d, $J=6.6$ Hz, H3-9, H3-8'), 2.17 (3H, s, H3-10'), 2.24 (3H, s, H3-11), 3.39 $(1 \mathrm{H}, \mathrm{dq}, J=7.0,3.5 \mathrm{~Hz}, \mathrm{H}-4), 3.51(1 \mathrm{H}, \mathrm{q}, J=6.6 \mathrm{~Hz}, \mathrm{H}-3), 4.73$ (dq, 6.8, 3.5 Hz, H-3'), 5.41 (1H, q, J=6.6 Hz, H-2'), 6.92 (1H, s, H-7). ESI ${ }^{+}-\mathrm{MS}: m / z, 381.2[\mathrm{M}+\mathrm{H}]^{+}$(calcd for $\mathrm{C}_{23} \mathrm{H}_{25} \mathrm{O}_{5}, 381.2$ ), ESI-MS: $m / z 379.3[\mathrm{M}-\mathrm{H}]^{-}\left(\right.$calcd for $\left.\mathrm{C}_{23} \mathrm{H}_{23} \mathrm{O}_{5}, 379.2\right)$.

Pinselin (17): amorphous solid. UV ( $\left.\lambda_{\max } \mathrm{nm}\right)$ : $235,263,295$, 384. ${ }^{1} \mathrm{H}$ NMR (400 MHz, TMS, DMSO- $\left.d_{6}\right): \delta(\mathrm{ppm}) ; 2.40(3 \mathrm{H}, \mathrm{s}$, H3-11), 3.85 (3H, s, H3-13), 6.66 (1H, s, H-2), 6.90 (1H, s, H-4), $7.49(1 \mathrm{H}, \mathrm{d}, J=8.0 \mathrm{~Hz}, \mathrm{H}-6), 7.61(1 \mathrm{H}, \mathrm{d}, J=8.0 \mathrm{~Hz}, \mathrm{H}-5), 8.40(1 \mathrm{H}$, s, OH-7), $12.19(1 \mathrm{H}, \mathrm{s}, \mathrm{OH}-1) \cdot{ }^{13} \mathrm{C}$ NMR (100 MHz, TMS, DMSO- $\left.d_{6}\right)$ : $\delta$ (ppm); 22.5 (C-11), 52.7 (C-13), 106.4 (C-3) 107.8 (C-4) 111.2 (C-1), 117.4 (C-4a), 117.6 (C-9a), 120.5 (C-2), 125.8 (C-10a), 149.1 (C-8a), 149.7 (C-8), 155.9 (C-7), 160.8 (C-5), 167.3 (C-12), 180.7 (C-9). ESI'-MS: $m / z, 323.1[\mathrm{M}+\mathrm{Na}]^{+}$(calcd for $\mathrm{C}_{16} \mathrm{H}_{12} \mathrm{NaO}_{6}, 323.1$ ), ESI-MS: $m / z, 299.2[\mathrm{M}+\mathrm{H}]^{-}$(calcd for $\mathrm{C}_{16} \mathrm{H}_{11} \mathrm{O}_{6}, 299.1$ ).

Emodin (18): yellow amorphous solid. UV $\left(\lambda_{\max } \mathrm{nm}\right)$ : 221, 266, 287. ${ }^{1} \mathrm{H}$ NMR (400 MHz, TMS, DMSO- $\left.d_{6}\right): \delta(\mathrm{ppm}) ; 2.38(3 \mathrm{H}, \mathrm{s}, \mathrm{H} 3-11)$, $6.56(1 \mathrm{H}, \mathrm{d}, J=4.0 \mathrm{~Hz}, \mathrm{H}-6), 7.08(1 \mathrm{H}, \mathrm{d}, J=4.0 \mathrm{~Hz}, \mathrm{H}-8), 7.12(1 \mathrm{H}$, br s, H-2), 7.44 (1H, br s, H-4), $11.34(1 \mathrm{H}, \mathrm{s}, \mathrm{OH}-1), 11.96(1 \mathrm{H}, \mathrm{s}$, OH-7), 12.04 (1H, s, OH-5). ${ }^{13} \mathrm{C}$ NMR (100 MHz, TMS, DMSO- $d_{6}$ ): $\delta$ (ppm); 21.9 (C-11), 108.3 (C-8), 109.1 (C-10a), 109.3 (C-4a), 113.8 (C-6), 120.9 (C-4), 124.5 (C-2), 133.2 (C-9a), 135.5 (C-8a), 148.7 (C3), 161.8 (C-1), 164.9 (C-7), 166.0 (C-5), 181.7 (C-9), 190.1 (C-10). ESI+-MS: $m / z, 271.2[\mathrm{M}+\mathrm{H}]^{+}$(calcd for $\mathrm{C}_{15} \mathrm{H}_{11} \mathrm{O}_{5}, 271.1$ ).

Quinolactacin B (19): white powder. UV $\left(\lambda_{\max } \mathrm{nm}\right)$ : 213,256 , 315. ${ }^{1} \mathrm{H}$ NMR see ref. $27 . \mathrm{ESI}^{+}-\mathrm{MS}: \mathrm{m} / z, 257.2[\mathrm{M}+\mathrm{H}]^{+}$(calcd for $\left.\mathrm{C}_{15} \mathrm{H}_{17} \mathrm{~N}_{2} \mathrm{O}_{2}, 257.1\right)$.
Penicillenol A (20): yellow oil. UV ( $\left.\lambda_{\max } \mathrm{nm}\right): 224,283 .{ }^{1} \mathrm{H}$ NMR (400 MHz, TMS, DMSO- $d_{6}$ ): $\delta$ (ppm); 0.86 (3H, t, $\left.J=6.4 \mathrm{~Hz}, \mathrm{H} 3-15\right)$, 1.14 ( $3 \mathrm{H}, \mathrm{d}, J=6.6 \mathrm{~Hz}, \mathrm{H} 3-7), 1.18$ (3H, d, $J=6.6 \mathrm{~Hz}, \mathrm{H} 3-16), 1.45$ $\left(1 \mathrm{H}, \mathrm{m}, \mathrm{H}-10_{\mathrm{B}}\right), 1.25$ (8H, br s, H2-11, H2-12, H2-13, H2-14), 1.69 $\left(1 \mathrm{H}, \mathrm{m}, \mathrm{H}-10_{\mathrm{A}}\right), 2.99$ (3H, s, H3-17), $3.56(1 \mathrm{H}, \mathrm{m}, \mathrm{H}-9), 3.81(1 \mathrm{H}$, d, J=4.8 Hz, H-5), 4.19 (1H, m, H-6). ${ }^{13} \mathrm{C}$ NMR (100 MHz, TMS, DMSO- $\left.d_{6}\right)$ : $\delta$ (ppm); 14.0 (C-15), 17.2 (C-16), 17.8 (C-7), $22.6(\mathrm{C}-$ 13), 27.1 (C-11), 27.2 (C-17), 29.2 (C-12), 31.7 (C-14), 33.6 (C-10), 36.6 (C-9), 66.7 (C-6), 70.9 (C-5), 193.3 (C-8). ESI+-MS: m/z, 298.3 $[\mathrm{M}+\mathrm{H}]^{+}\left(\right.$calcd for $\left.\mathrm{C}_{16} \mathrm{H}_{28} \mathrm{NO}_{4}, 298.2\right)$.

Citreorosein (21): yellow powder. UV $\left(\lambda_{\max } \mathrm{nm}\right): 221,287 .{ }^{1} \mathrm{H} \mathrm{NMR}$ (400 MHz, TMS, DMSO- $\left.d_{6}\right): \delta$ (ppm); $4.60(2 \mathrm{H}, \mathrm{s}, \mathrm{H} 2-11), 6.56(1 \mathrm{H}$, d, $J=2.4 \mathrm{~Hz}, \mathrm{H}-2), 7.09$ (1H, d, $J=2.4 \mathrm{~Hz}, \mathrm{H}-4), 7.23$ (1H, d, $J=1.4$ $\mathrm{Hz}, \mathrm{H}-7), 7.62$ (d, J=1.4 Hz, 1H, H-5). ${ }^{13} \mathrm{C}$ NMR (100 MHz, TMS, DMSO- $d_{6}$ ): $\delta$ (ppm); 189.5 (C-9), 181.3 (C-10), 165.9 (C-1), 164.4 (C-3), 161.4 (C-8), 152.7 (C-6), 135.0 (C-4a), 132.8 (C-10a), 120.7 (C7), 117.0 (C-5), 114.0 (C-8a), 108.9 (C-9a), 108.7 (C-4), 107.8 (C-2), $61.9(\mathrm{C}-11)$. ESI ${ }^{+}-\mathrm{MS}: \mathrm{m} / z, 287.1[\mathrm{M}+\mathrm{H}]^{+}$(calcd for $\mathrm{C}_{15} \mathrm{H}_{11} \mathrm{O}_{6}, 287.1$ ).

Quinolactacin $C(\mathbf{2 2})$ : white powder. UV $\left(\lambda_{\max } \mathrm{nm}\right)$ : 218,250 , 316. ${ }^{1} \mathrm{H}$ NMR and ${ }^{13} \mathrm{C}$ NMR see ref. 27. ESI+-MS: $m / z$, $287.0[\mathrm{M}+\mathrm{H}]^{+}$ (calcd for $\mathrm{C}_{16} \mathrm{H}_{19} \mathrm{~N}_{2} \mathrm{O}_{3}, 287.1$ ).

5-Methylmellein (23): white crystal. UV $\left(\lambda_{\max } \mathrm{nm}\right): 248,322 .{ }^{1} \mathrm{H}$ NMR (500 MHz, TMS, MeOH- $\left.d_{4}\right): \delta(\mathrm{ppm}) ; 1.51(3 \mathrm{H}, \mathrm{d}, J=6.31 \mathrm{~Hz}$, H3-3'), 2.21 (3H, s, H3-5'), 2.72 (1H, dd, J=16.9, 11.5 Hz, H-4 ${ }_{\mathrm{A}}$, $3.06\left(1 \mathrm{H}, \mathrm{dd}, J=16.9,3.6 \mathrm{~Hz}, \mathrm{H}-4_{\mathrm{B}}\right), 4.70(1 \mathrm{H}, \mathrm{m}, \mathrm{H}-3), 6.76(1 \mathrm{H}, \mathrm{d}$, $J=7.1 \mathrm{~Hz}, \mathrm{H}-6), 7.34(1 \mathrm{H}, \mathrm{d}, J=7.1 \mathrm{~Hz}, \mathrm{H}-7) .{ }^{13} \mathrm{C}$ NMR $(125 \mathrm{MHz}$, TMS, MeOH- $\left.d_{4}\right): \delta(\mathrm{ppm}) ; 18.3$ (C-3'), 21.1 (C-5'), $32.6(\mathrm{C}-4), 77.2$ (C-3), 109.1 (C-9), 116.3 (C-5), 126.7 (C-7), 139.0 (C-6), 139.1 (C10), 161.6 (C-8), 172.0 (C-1). ESI+-MS: $m / z, 193.2[\mathrm{M}+\mathrm{H}]^{+}$(calcd for $\left.\mathrm{C}_{11} \mathrm{H}_{13} \mathrm{O}_{3}, 193.1\right)$. $[\alpha]_{\mathrm{D}}{ }^{25}-81$ (c $\left.1.24, \mathrm{MeOH}\right)$.

5,7-Dichloro-3-methyl-6-methoxy-8-hydroxy-3,4dihydroisocoumarin (24): white crystal. UV $\left(\lambda_{\max } \mathrm{nm}\right): 218,254$, 322. ${ }^{1} \mathrm{H}$ NMR (500 MHz, TMS, DMSO- $\left.d_{6}\right): \delta(\mathrm{ppm}) ; 1.40(3 \mathrm{H}, \mathrm{d}$, $\left.J=6.34 \mathrm{~Hz}, \mathrm{H} 3-3^{\prime}\right), 2.76$ (1H, dd, $\left.J=16.9,11.6 \mathrm{~Hz}, \mathrm{H}-4_{\mathrm{A}}\right), 3.14(1 \mathrm{H}$, dd, $J=16.8,3.4$ Hz, H-4 B , 4.57 (1H, m, H-3), 3.82 (3H, s, H3-6'). ${ }^{13} \mathrm{C}$ NMR (125 MHz, TMS, DMSO- $\left.d_{6}\right)$ : $\delta$ (ppm); 20.9 (C-3'), 32.8 (C-4), 61.3 (C-6'), 72.8 (C-3), 111.3 (C-9), 115.1 (C-7), 115.9 (C-5), 138.6 (C-10), 154.3 (C-8), 157.3 (C-6), 160.4 (C-1). ESI ${ }^{+}-\mathrm{MS}: \mathrm{m} / \mathrm{z}$ $275.1[\mathrm{M}+\mathrm{H}]^{+}$(calcd for $\left.\mathrm{C}_{11} \mathrm{H}_{10} \mathrm{Cl}_{2} \mathrm{O}_{4}, 275.9\right)$.

(+)-Abscisic acid (25): amorphous solid. UV $\left(\lambda_{\max } \mathrm{nm}\right): 261 .{ }^{1} \mathrm{H}$ NMR (500 MHz, TMS, MeOH- $\left.d_{4}\right): \delta(\mathrm{ppm}) ; 1.02$ (3H, s, H3-7'), 1.06 (3H, s, H3-8'), 1.93 (3H, s, H3-9'), 2.03 (3H, s, H3-6), 2.18 (1H, d, $\left.J=22.5 \mathrm{~Hz}, \mathrm{H}-5{ }_{\mathrm{A}}\right), 2.53\left(1 \mathrm{H}, \mathrm{d}, J=22.5 \mathrm{~Hz}, \mathrm{H}-5{ }^{\prime}{ }_{\mathrm{B}}\right), 5.74(1 \mathrm{H}, \mathrm{s}, \mathrm{H}-2)$, $5.92\left(1 \mathrm{H}, \mathrm{s}, \mathrm{H}-3^{\prime}\right), 6.23(1 \mathrm{H}, \mathrm{d}, J=20.0 \mathrm{~Hz}, \mathrm{H}-5), 7.76(1 \mathrm{H}, \mathrm{d}, J=20.0$ $\mathrm{Hz}, \mathrm{H}-4) .{ }^{13} \mathrm{C}$ NMR $\left(125 \mathrm{MHz}, \mathrm{TMS}, \mathrm{MeOH}-d_{4}\right): \delta(\mathrm{ppm}) ; 18.19(\mathrm{C}-$ 9'), 19.8 (C-6), 22.1 (C-7'), 23.2 (C-8'), 41.4 (C-6'), 49.2 (C-5), 79.2 (C-1'), 118.4 (C-2), 126.14 (C-3'), 128.0 (C-4), 136.4 (C-5), 149.4 (C-2'), 165.1 (C-3), 168.2 (C-1), 199.6 (C-4').ESI+MS: m/z 287.3 $[\mathrm{M}+\mathrm{Na}]^{+}$(calcd for $\left.\mathrm{C}_{15} \mathrm{H}_{20} \mathrm{O}_{4} \mathrm{Na}, 287.1\right)$. $[\alpha]_{\mathrm{D}}{ }^{25}+87$ (c 2.0, MeOH).

4-hydroxy-3-prenyl-benzoic acid (26): amorphous solid. UV $\left(\lambda_{\max } \mathrm{nm}\right): 259 .{ }^{1} \mathrm{H}$ NMR $\left(600 \mathrm{MHz}, \mathrm{TMS}, \mathrm{MeOH}-d_{4}\right): \delta(\mathrm{ppm}) ; 1.72$ (3H, br s, H3-11), 1.75 (3H, d, $J=1.3 \mathrm{~Hz}, \mathrm{H} 3-12), 3.30$ (1H, d, $J=7.7$ Hz, H-8), 6.77 (1H, d, J=8.4 Hz, H-5), 5.32 (1H, tseptet, $J=7.7,1.3$ Hz, H-9), 7.69 (1H, dd, J=8.4, 2.2 Hz, H-6), 7.74 (1H, d, J=2.2 Hz, $\mathrm{H}-2) .{ }^{13} \mathrm{C}$ NMR (150 MHz, TMS, MeOH- $\left.d_{4}\right): \delta$ (ppm); 17.9 (C-12), 26.0 (C-11), 29.1 (C-8), 115.2 (C-1, C-5), 123.4 (C-9), 129.2 (C-3), 130.4 (C-6), 132.5 (C-2), 133.6 (C-10), 160.8 (C-4), 171.1 (C-7). ESI+-MS: $m / z, 207.2[\mathrm{M}+\mathrm{H}]^{+}\left(\right.$calcd for $\left.\mathrm{C}_{12} \mathrm{H}_{15} \mathrm{O}_{3}, 207.1\right)$.

Anofinic acid (27): amorphous solid. UV ( $\left.\lambda_{\max } \mathrm{nm}\right): 239 .{ }^{1} \mathrm{H}$ NMR (600 MHz, TMS, MeOH- $\left.d_{4}\right): \delta$ (ppm); 1.43 (6H, s, H3-9, H3-10), $5.70(1 \mathrm{H}, \mathrm{d}, J=9.9 \mathrm{~Hz}, \mathrm{H}-3), 6.41(1 \mathrm{H}, \mathrm{d}, J=9.9 \mathrm{~Hz}, \mathrm{H}-4), 6.69(1 \mathrm{H}, \mathrm{d}$, $J=8.7 \mathrm{~Hz}, \mathrm{H}-8), 7.64$ (1H, br s, H-5), 7.74 (1H, br d, $J=8.7 \mathrm{~Hz}, \mathrm{H}-7)$. ESI ${ }^{+}-\mathrm{MS}: m / z, 205.3[\mathrm{M}+\mathrm{H}]^{+}$(calcd for $\left.\mathrm{C}_{12} \mathrm{H}_{13} \mathrm{O}_{3}, 205.1\right)$. 
2,3-Dihydro-6,7-dihydroxy-2,2-dimethylchromen-4-one (28): amorphous solid. UV $\left(\lambda_{\max } \mathrm{nm}\right): 240,279,347 .{ }^{1} \mathrm{H}$ NMR $(600 \mathrm{MHz}$, TMS, MeOH- $\left.d_{4}\right): \delta(\mathrm{ppm}) ; 1.40(6 \mathrm{H}, \mathrm{s}, \mathrm{H} 3-9, \mathrm{H} 3-10), 2.61(2 \mathrm{H}, \mathrm{s}$, H2-3), 6.28 (1H, s, H-8), 7.13 (1H, s, H-5). ${ }^{13} \mathrm{C}$ NMR $(150 \mathrm{MHz}$, TMS, MeOH- $\left.d_{4}\right): \delta(\mathrm{ppm}) ; 26.8$ (C-9, C-10), 49.3 (C-3), 80.1 (C-2), 104.6 (C-8), 111.1 (C-5), 113.2 (C-4a), 141.7 (C-6), 156.4 (C-8a), 157.6 (C-7), 193.8 (C-4). ESI+-HRMS: $m / z, 209.08167[\mathrm{M}+\mathrm{H}]^{+}$(calcd for $\left.\mathrm{C}_{11} \mathrm{H}_{13} \mathrm{O}_{4}, 209.08138\right)$.

Harzianopyridone (29): amorphous solid. UV $\left(\lambda_{\max } \mathrm{nm}\right): 203$, 237, 269, 333. ${ }^{1} \mathrm{H}$ NMR (500 MHz, TMS, DMSO- $\left.d_{6}\right): \delta$ (ppm); 1.01 (3H, d, J=8.5 Hz, H3-9), 1.56 (3H, d, J=6.1 Hz, H3-13), 1.94 (1H, $\left.\mathrm{dt}, J=14.3,8.3 \mathrm{~Hz}, \mathrm{H}-10_{\mathrm{A}}\right), 2.35\left(1 \mathrm{H}, \mathrm{dt}, J=14.3,8.3 \mathrm{~Hz}, \mathrm{H}-10_{\mathrm{B}}\right), 3.57$ (3H, s, H3-15), 3.87 (3H, s, H3-14), 3.92 (1H, sextet, $J=8.5 \mathrm{~Hz}, \mathrm{H}-8)$, 5.33 (2H, m, H1-11, H1-12). ${ }^{13} \mathrm{C}$ NMR (125 MHz, TMS, DMSO- $d_{6}$ ): $\delta$ (ppm); 16.9 (C-9), 18.2 (C-13), 36.3 (C-10), 43.2 (C-8), $54.6(\mathrm{C}-15)$, 60.4 (C-14), 100.1 (C-3), 121.0 (C-5), 126.7 (C-12), 129.3 (C-11), 158.9 (C-6), 161.6 (C-2), 172.0 (C-4), 209.0 (C-7). ESI+-MS: m/z $282.2[\mathrm{M}+\mathrm{H}]^{+}$(calcd for $\left.\mathrm{C}_{14} \mathrm{H}_{20} \mathrm{NO}_{5}, 282.1\right)$.

Pyrenocine A (30): amorphous solid. UV $\left(\lambda_{\max } \mathrm{nm}\right): 228,274 .{ }^{1} \mathrm{H}$ NMR and ${ }^{13} \mathrm{C}$ NMR see refs. 14 and 35. ESI ${ }^{+}-\mathrm{MS}: m / z 209.0[\mathrm{M}+\mathrm{H}]^{+}$ (calcd for $\mathrm{C}_{11} \mathrm{H}_{12} \mathrm{O}_{4}, 209.1$ ).

Pyrenocine $B$ (31): amorphous solid. UV $\left(\lambda_{\max } \mathrm{nm}\right)$ : $262 .{ }^{1} \mathrm{H}$ NMR and ${ }^{13} \mathrm{C}$ NMR see refs. 14 and 35. ESI ${ }^{+}$-MS: $m / z, 227.0[\mathrm{M}+\mathrm{H}]^{+}$(calcd for $\mathrm{C}_{11} \mathrm{H}_{14} \mathrm{O}_{5}, 227.1$ ).

Conocenol B (32): colorless oil. UV $\left(\lambda_{\max } \mathrm{nm}\right)$ : $236.0 .{ }^{1} \mathrm{H} \mathrm{NMR}$ (400 MHz, TMS, DMSO- $d_{6}$ ): $\delta(\mathrm{ppm}) ; 2.48(3 \mathrm{H}, \mathrm{m}), 1.75(4 \mathrm{H}, \mathrm{m})$, $1.60(4 \mathrm{H}, \mathrm{m}), 3.73(5 \mathrm{H}, \mathrm{d}, J=11.0), 1.70(6 \mathrm{H}, \mathrm{m}), 2.93(7 \mathrm{H}, \mathrm{br} \mathrm{t}$,

$J=8.6 \mathrm{~Hz}), 1.37(8 \mathrm{H}, \mathrm{m}), 2.16(10 \mathrm{H}, \mathrm{dd}, J=1.6,1.6,14.48 \mathrm{~Hz})$, $1.80(10 \mathrm{H}$, br d, $J=13.3 \mathrm{~Hz}), 3.90(11 \mathrm{H}, \mathrm{m}), 3.53(12 \mathrm{H}, \mathrm{d}, J=6.0 \mathrm{~Hz})$, $0.85(13 \mathrm{H}, \mathrm{d}, J=6.8 \mathrm{~Hz}), 1.02(14 \mathrm{H}, \mathrm{s}), 0.79(15 \mathrm{H}, \mathrm{s})$. ESI ${ }^{+}-\mathrm{MS}: \mathrm{m} / z$ $277[\mathrm{M}+\mathrm{Na}]^{+}\left(\right.$calcd for $\left.\mathrm{C}_{15} \mathrm{H}_{26} \mathrm{O}_{3} \mathrm{Na}, 277.1779\right) .[\alpha]_{\mathrm{D}}^{14.7}+84.4(\mathrm{c}$ $0.15, \mathrm{MeOH})$.

\section{Antiviral assays}

Virus and cell lines: Cell lines were propagated in monolayer cultures using a minimal essential medium (MEM) with Earle's salts supplemented with $10 \%$ fetal bovine serum (FBS). The cells were inoculated at 1:2 to 1:10 dilutions. When a virus was used with the cells, it was necessary to use medium without FBS. ${ }^{37}$

Cell cytotoxic effect: Cell suspensions ( $100 \mu \mathrm{L}$ per well $)$ were seeded into 96-well culture plates at a density of 1 x $10^{5}$ cells $/ \mathrm{mL}$. The microtiter plates containing the cells were pre-incubated for 24 $\mathrm{h}$ at $37^{\circ} \mathrm{C}$ to allow for stabilization prior to the addition of $100 \mu \mathrm{L}$ aliquots of selected compounds at four concentrations: 0.25, 2.5, 25, and $250 \mu \mathrm{g} \mathrm{mL}^{-1}$. The maximum nontoxic concentration (MNTC) was determined microscopically by observing the morphological changes of the cells at 24, 48 and 72 hours of incubation. After $72 \mathrm{~h}$, a (3-(4,5-Dimethylthiazol-2-yl)-2,5-Diphenyltetrazolium Bromide) (MTT) assay was performed in order to evaluate the cytotoxic activity of the compounds. ${ }^{37}$

Titration of viruses: Cells were seeded in 96 -well culture plates at a density of $1 \times 10^{5}$ cells $/ \mathrm{mL}$ and incubated at $37^{\circ} \mathrm{C}$ for $24 \mathrm{~h}$ in a humidified atmosphere containing $\mathrm{CO}_{2}$. Serial dilutions of the virus stocks were prepared and used to infect the cells. After an additional incubation of 1 to 2 days, the cytopathic effect was recorded. The $50 \%$ infective doses in tissue culture $\left(\mathrm{TCID}_{50 \mathrm{uL}}\right.$ ) was calculated as previously described. ${ }^{37}$

Antiviral activity: Determination of the antiviral activity was based on cytopathic effect. All experiments were performed in triplicate. Briefly, cells were seeded in 96-well culture plates and, after $24 \mathrm{~h}$ of incubation, the medium was replaced with $100 \mu \mathrm{L}$ Dulbecco's Modified Eagle Medium (DMEM) containing the selected compounds at the MNTC. Then, $50 \mu \mathrm{L}$ logarithmic dilutions of viruses were added in quadruplicate and incubated for 2 to 5 days, depending on the virus. Controls were untreated infected (virus titer), treated noninfected (control), and untreated noninfected. The viral titers were determined by the $50 \%$ infective doses in tissue culture $\left(\mathrm{TCID}_{50 \mathrm{~L}}\right)$. The antiviral activity was determined as the logarithm reduction factor $\left(\log _{10}\right)$ of the viral titer compared to the untreated infected controls. The values are expressed as titer $\left(\mathrm{TCID}_{50 \mathrm{LL}}\right)$ and inhibition percentage (IP). The inhibition percentage was calculated using the formula $(\mathrm{IP})=(1-\mathrm{T} / \mathrm{C}) \times 100$, where $\mathrm{T}$ is the antilog of the sample-treated viral titers and $\mathrm{C}$ is the antilog of the control (without sample treatment with pure compounds) viral titers. The IP was considered to be positive if greater than or equal to $98 \%$.

The antiviral activity was initially evaluated with a single dose at the MNTC against different viral concentrations. Compounds were considered positively active when there was a $1.5 \log$ decrease in the viral titer. To confirm the antiviral activity, a concentration response curve with different concentrations of the selected compounds in the presence of $100 \mathrm{TCID}_{50} / \mathrm{mL}$ was determined by the MTT assay, in order to establish the $50 \%$ antiviral concentration $\left(\mathrm{EC}_{50}\right)$. Briefly, $5 \mathrm{mg} \mathrm{mL}^{-1}$ of the MTT solution in PBS were added to 96-well culture plates at $20 \mu \mathrm{l} /$ well at each time point. Following a $4 \mathrm{~h}$ incubation, $100 \mu \mathrm{L}$ of dimethylsulfoxide (DMSO) were added to each well and mixed thoroughly to dissolve the dark-blue formazan crystals. Plates were read on an ELISA reader (Molecular Devices SpectraMax Plus) at a wavelength of $540 \mathrm{~nm} \cdot{ }^{37}$

Data analysis: The $50 \%$ cytotoxic $\left(\mathrm{CC}_{50}\right)$ and $50 \%$ inhibition $\left(\mathrm{IC}_{50}\right)$ concentrations were calculated from concentration-effect curves (data not shown). The results were obtained from triplicate assays with at least five different concentrations for each tested compound. The percentage of cytotoxicity was calculated as $[(\mathrm{A}-\mathrm{B}) / \mathrm{A}] \mathrm{x} 100$, where $A$ and $B$ were the optical density measured at $\lambda_{\max }=540 \mathrm{~nm}$ $\left(\mathrm{OD}_{540}\right)$ of the untreated and treated cells, respectively. The percentages of protection were calculated as $[(A-B) \times 100 /(C-B)]$, where $\mathrm{A}, \mathrm{B}$ and $\mathrm{C}$ indicate the absorbance of compounds, virus, and cell controls, respectively. Each $\mathrm{EC}_{50}$ value was defined as the effective concentration that reduced the absorbance of the infected cells to $50 \%$ compared to the cell and virus controls. The therapeutic index (i.e., selective index) was defined as $\mathrm{CC}_{50} / \mathrm{EC}_{50} \cdot{ }^{37}$

Potential stage in the viral infection cycle: Cells and viruses were incubated with compounds $\mathbf{2 9}$ and 30, separately, at different stages during the viral infection cycle to establish the mode of antiviral action. Cells were either pretreated with the compounds before viral infection, the viruses were incubated with the compounds before cell infection, or the cells were infected with the virus and incubated together before the addition of the compounds. The samples were used at the maximum noncytotoxic concentration and maintained during all experiment. ${ }^{37}$

Viral inactivation: To determine whether compounds inactivate extracellular virus, equal volumes $(100 \mu \mathrm{L})$ of 10 -fold serially diluted virus suspension and the MNTC were mixed and incubated for $1 \mathrm{~h}$ at $37^{\circ} \mathrm{C}$. Each mixture was then added to the cell monolayer, and the infectious titers were compared to the controls. ${ }^{37}$

Statistical analysis: The results are expressed as the mean \pm s.e.m. The selectivity index (SI) is the ratio of $\mathrm{CC}_{50}$ to $\mathrm{EC}_{50}$. The significantly different effects of compounds on the inhibition of virus replication were compared to the control group using Student's t-test, with $\mathrm{p} \leq 0.05$ indicating a significant result. ${ }^{37}$

\section{RESULTS AND DISCUSSION}

The isolation of new, biologically active fungal metabolites is a major challenge, considering the very large number of fungal 


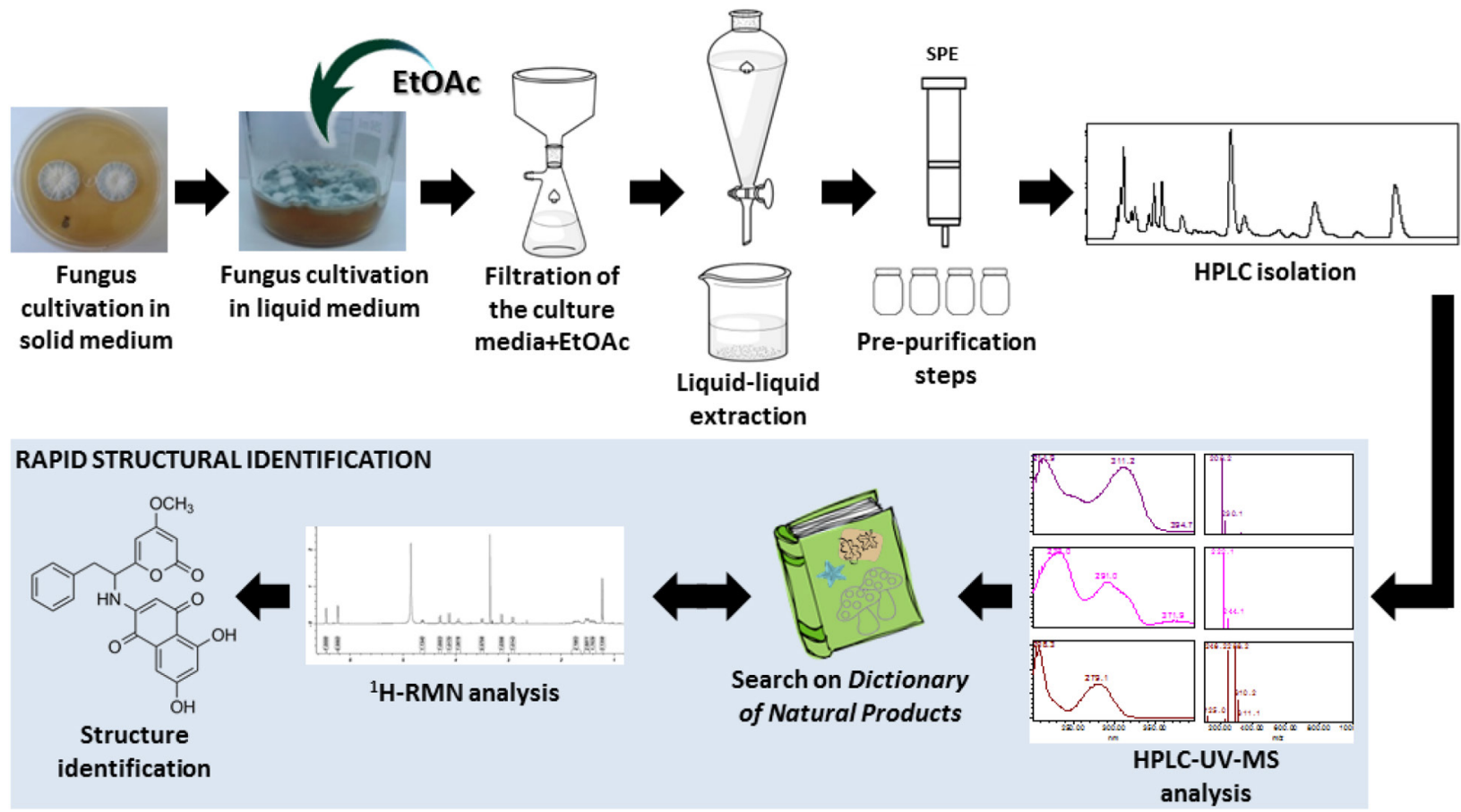

Scheme 1. Secondary metabolites dereplication process and rapid structural identification

metabolites isolated so far. ${ }^{5}$ Therefore, a good strategy to access rapid identification of fungal metabolites is mandatory when high-throughput, high resolution, and sensitive instrumentation for dereplication purposes is unavailable.

The approach herein presented was based on easily available and low cost spectroscopic identification techniques: UV spectra, low-resolution mass spectrometry and ${ }^{1} \mathrm{H}$ MNR data. Strains were grown in media previously selected ${ }^{14}$ in order to produce an adequate amount of material for the isolation of secondary metabolite enriched fractions and/or pure compounds. Isolation was performed by several chromatographic steps, including gel-permeation, reversed-phase and normal-phase chromatography. Analysis of fractions by HPLCUV-MS and in bioassays provided key results to pursue the isolation of pure compounds. UV maxima were recorded together with $\mathrm{m} / \mathrm{z}$ values observed for $[\mathrm{M}+\mathrm{H}]^{+},[\mathrm{M}-\mathrm{H}]^{-}$and $[\mathrm{M}+\mathrm{Na}]^{+}$ions, which were often detected. Data obtained were enough to provide sufficient information for the identification of most of the metabolites isolated as pure chemical entities. This approach is summarized in Scheme 1.

One of the difficulties in querying databases such as the Dictionary of Natural Products and MarinLit is the return of a very large number of results if the molecular formula is not known by HRMS analysis. Such outcome makes the identification process laborious and time consuming.

The use of ${ }^{1} \mathrm{H}$ NMR and, when necessary, ${ }^{13} \mathrm{C}$ NMR analysis provided additional information when the structural information of the metabolites detected in the HPLC-UV-MS screening process did not have unique UV absorptions that gave a single match or few matches during identification. Rapid identification after the purification process instead of dereplication during the analysis of crude extracts is suitable when: a) there are inherent difficulties in applying dereplication to complex mixtures (e.g., instrumentation limitation or limited access to databases); b) the identification of pure metabolites is required for the construction of an "in-house" database, and; c) the isolated compounds display relevant and potent biological activity.

An example that illustrates the effectiveness of the rapid identification approach is the identification of sydowic acid (7). This metabolite was isolated from the culture medium of the marine-derived strain A. sydowii DRG1M2. It has a molecular weight of $264 \mathrm{Da}$ that matches other 58 fungal metabolites in the DNP database (Table 2). The identification of (7) was possible by analysis of LRMS and UV spectra together with analysis of its ${ }^{1} \mathrm{H}$ NMR spectrum, which showed three methyl signals at $\delta 0.97$ (s), $\delta 0.98(\mathrm{~s})$, and $\delta 1.50(\mathrm{~s})$, one trisubstituted benzene moiety with ${ }^{1} \mathrm{H}$ signals at $\delta 7.28(\mathrm{~d}, 1.7 \mathrm{~Hz}), \delta 7.33(\mathrm{dd}, 8.0$ and $1.7 \mathrm{~Hz}), \delta 7.38$ $(\mathrm{d}, 8.0 \mathrm{~Hz})$, and a carboxylic acid ${ }^{1} \mathrm{H}$ at $\delta 9.98$ (s). Comparison of sydowic acid (7) ${ }^{1} \mathrm{H}$ NMR data with the structures of compounds with the same molecular weight and similar UV absorption obtained in the DNP enabled its rapid identification, ${ }^{16}$ with no need for further NMR analyses. This approach defrayed the costs of time-consuming NMR experiments and provided rapid access to the structures of an extensive number of known fungal metabolites, many of which have been isolated several decades ago, when bioassays to evaluate such metabolites were still very limited.

Of the twenty-six compounds herein reported, the structures of $(\mathbf{8})$ and (28) have not been previously reported in the literature. Compound (8) was identified as the opposite enantiomer of (+)-5,7-dihydroxy-2-[1-(4-methoxy-6-oxo-6H-pyran-2-yl)-2-phenylethylamino]-[1,4]naphthoquinone. ${ }^{17}$ It was isolated as a red amorphous solid and presented a $[\mathrm{M}+\mathrm{H}]^{+}$ion at $m / z$ 434.0. Analysis of its ${ }^{1} \mathrm{H}$ NMR spectrum indicated signals characteristic of a monosubstituted benzene ring at $\delta 7.30(\mathrm{~m}), \delta 7.28(\mathrm{~m})$, and $\delta 7.23(\mathrm{~m})$. Two hydrogens observed at $\delta 6.96(\mathrm{~d}, 2.3 \mathrm{~Hz})$ and $\delta 6.51(\mathrm{~d}, 2.4 \mathrm{~Hz})$ were assigned to a tetrasubstituted benzene moiety. Hydrogens characteristic of a pyrone group at $\delta 5.98(\mathrm{~d}, 2.3 \mathrm{~Hz})$ and $\delta 5.45(\mathrm{~d}, 2.3 \mathrm{~Hz})$ were detected, along with a proton at $\delta 5.59(\mathrm{~s})$ attached to a $\mathrm{sp}^{2}$ carbon, and two singlets at $\delta 12.91$ (s) and at $\delta 3.77$ (s) assigned to a hydroxyl and methoxyl groups, respectively. Finally, two diastereotopic hydrogens were observed at $\delta 3.31(\mathrm{dd}, 13.9 ; 6.0 \mathrm{~Hz})$ and $\delta 6.21(\mathrm{dd}, 13.9 ; 8.2$ $\mathrm{Hz}$ ). Analysis of its ${ }^{13} \mathrm{C}$ NMR spectrum confirmed the presence of a monosubstituted benzene ring at $\delta 132.1,129.2$ (2C), 128.6 (2C) and 127.1, the tetrasubstituted aromatic ring at $\delta 163.4,161.0,136.3$, $108.9,108.8,107.9$, the pyrone ring at $\delta 170.7,163.3,163.2,101.2$, 88.3 , and a methoxyl group at $\delta$ 56.2. Two additional $\mathrm{sp}^{2}$ carbon signals were observed at $\delta 147.5,100.4$, a heteroatom-substituted 
Table 1. Secondary metabolites identified by HPLC-UV-MS and ${ }^{1} \mathrm{H}$ NMR analysis

\begin{tabular}{|c|c|c|c|c|}
\hline Compounds & Filamentous fungi (strain) & Molecular formula & $\mathrm{UV}\left(\lambda_{\max } \mathrm{nm}\right)$ & MS data $(\mathrm{m} / \mathrm{z})$ \\
\hline Sydowic acid (7) & A. sydowii (DRG1M2) & $\mathrm{C}_{24} \mathrm{H}_{20} \mathrm{NO}_{7}$ & $212,244,299$ & $247\left[\mathrm{M}-\mathrm{H}_{2} \mathrm{O}\right]^{+}$ \\
\hline Naphthoquinoneimine (8) & Aspergillus sp. (DLM38) & $\mathrm{C}_{32} \mathrm{H}_{27} \mathrm{O}_{10}$ & $207,270,334$ & $434.0[\mathrm{M}+\mathrm{H}]^{+}$ \\
\hline Aurosperone A (9) & Aspergillus sp. (DLM38) & $\mathrm{C}_{32} \mathrm{H}_{26} \mathrm{O}_{10}$ & $228,258,277$ & $571.1[\mathrm{M}+\mathrm{H}]^{+}$ \\
\hline Pyranonigrin C (10) & Aspergillus sp. (DLM38) & $\mathrm{C}_{22} \mathrm{H}_{22} \mathrm{~N}_{2} \mathrm{O}_{12}$ & $231,290,329$ & $254.4[\mathrm{M}+\mathrm{H}]^{+}$ \\
\hline Aurosperone C (11) & Aspergillus sp. (DLM38) & $\mathrm{C}_{31} \mathrm{H}_{29} \mathrm{O}_{12}$ & $233,282,334$ & $593.1[\mathrm{M}+\mathrm{H}]^{+}$ \\
\hline Pyrophen (12) & Aspergillus sp. (DLM38) & $\mathrm{C}_{16} \mathrm{H}_{17} \mathrm{NO}_{4}$ & 265 & $323.2[\mathrm{M}+\mathrm{Cl}]^{-}$ \\
\hline Leucomelone (13) & Aspergillus sp. (DLM38) & $\mathrm{C}_{18} \mathrm{H}_{11} \mathrm{O} 7$ & 265 & $339.2[\mathrm{M}-\mathrm{H}]^{-}$ \\
\hline Atromentin (14) & Aspergillus sp. (DLM38) & $\mathrm{C}_{18} \mathrm{H}_{11} \mathrm{O} 6$ & 266 & $323.2[\mathrm{M}-\mathrm{H}]^{-}$ \\
\hline Pyranonigrin B (15) & Aspergillus sp. (DLM38) & $\mathrm{C}_{22} \mathrm{H}_{22} \mathrm{~N}_{2} \mathrm{O}_{12}$ & $233,291,371$ & $254.1[\mathrm{M}+\mathrm{H}]^{+}$ \\
\hline Penicitrinone A (16) & P. glabrum (DLM218) & $\mathrm{C}_{23} \mathrm{H}_{23} \mathrm{O}_{5}$ & $283,307,383$ & $381.2[\mathrm{M}+\mathrm{H}]^{+}$ \\
\hline Pinselin (17) & P. glabrum (DLM218) & $\mathrm{C}_{16} \mathrm{H}_{11} \mathrm{O}_{6}$ & $235,263,295,384$ & $323.1[\mathrm{M}+\mathrm{Na}]^{+}$ \\
\hline Emodin (18) & $\begin{array}{l}\text { P. glabrum (DLM218) and } \\
\text { P. citrinum (DLM212) }\end{array}$ & $\mathrm{C}_{15} \mathrm{H}_{11} \mathrm{O}_{5}$ & $221,266,287$ & $271.2[\mathrm{M}+\mathrm{H}]^{+}$ \\
\hline Quinolactacin B (19) & P. citrinum (DLM212) & $\mathrm{C}_{15} \mathrm{H}_{16} \mathrm{~N}_{2} \mathrm{O}_{2}$ & $213,256,315$ & $257.2[\mathrm{M}+\mathrm{H}]^{+}$ \\
\hline Penicillenol A (20) & P. citrinum (DLM212) & $\mathrm{C}_{16} \mathrm{H}_{27} \mathrm{NO}_{4}$ & 224,283 & $298.3[\mathrm{M}+\mathrm{H}]^{+}$ \\
\hline Citreorosein (21) & P. citrinum (DLM212) & $\mathrm{C}_{15} \mathrm{H}_{10} \mathrm{O}_{6}$ & 221,287 & $287.1[\mathrm{M}+\mathrm{H}]^{+}$ \\
\hline Quinolactacin C (22) & P. citrinum (DLM212) & $\mathrm{C}_{16} \mathrm{H}_{18} \mathrm{~N}_{2} \mathrm{O}_{3}$ & $218,250,316$ & $287.0[\mathrm{M}+\mathrm{H}]^{+}$ \\
\hline 5-methylmellein (23) & Roussoella sp. (DLM33) & $\mathrm{C}_{11} \mathrm{H}_{12} \mathrm{O}_{3}$ & 248,322 & $193.2[\mathrm{M}+\mathrm{H}]^{+}$ \\
\hline $\begin{array}{l}\text { 5,7-Dichloro-3-methyl-6-methoxy-8-hydroxy-3,4-dihy- } \\
\text { droisocoumarin (24) }\end{array}$ & Roussoella sp. (DLM33) & $\mathrm{C}_{12} \mathrm{H}_{15} \mathrm{O}_{3}$ & 259 & $207.2[\mathrm{M}+\mathrm{H}]^{+}$ \\
\hline (+)-abscisic acid (25) & Cochliobolus sp. (F56) & $\mathrm{C}_{15} \mathrm{H}_{20} \mathrm{O}_{4}$ & 261 & $287.3[\mathrm{M}+\mathrm{Na}]^{+}$ \\
\hline 4-hydroxy-3-prenyl-benzoic acid (26) & Cochliobolus sp. (F56) & $\mathrm{C}_{12} \mathrm{H}_{14} \mathrm{O}_{3}$ & 259 & $207.2[\mathrm{M}+\mathrm{H}]^{+}$ \\
\hline Anofinic acid (27) & Cochliobolus sp. (F56) & $\mathrm{C}_{12} \mathrm{H}_{12} \mathrm{O}_{3}$ & 239 & $205.3[\mathrm{M}+\mathrm{H}]^{+}$ \\
\hline 6,7-dihydroxy-2,2-dimethyl-4-chromanone (28) & Cochliobolus sp. (F56) & $\mathrm{C}_{11} \mathrm{H}_{12} \mathrm{O}_{4}$ & $240,279,347$ & $209.1[\mathrm{M}+\mathrm{H}]^{+}$ \\
\hline Harzianopyridone (29) & Trichoderma sp. (F254) & $\mathrm{C}_{14} \mathrm{H}_{19} \mathrm{NO}_{5}$ & $203,237,269,333$ & $282.2[\mathrm{M}+\mathrm{H}]^{+}$ \\
\hline Pyrenocine A (30) & P. paxilli $(\mathrm{Ma}(\mathrm{G}) \mathrm{K})$ & $\mathrm{C}_{11} \mathrm{H}_{12} \mathrm{O}_{4}$ & 228,274 & $209.0[\mathrm{M}+\mathrm{H}]^{+}$ \\
\hline Pyrenocine B (31) & P. paxilli $(\mathrm{Ma}(\mathrm{G}) \mathrm{K})$ & $\mathrm{C}_{11} \mathrm{H}_{14} \mathrm{O}_{5}$ & 262 & $272.0[\mathrm{M}+\mathrm{H}]^{+}$ \\
\hline Conocenol B (32) & Unidentified (P1AF2F3) & $\mathrm{C}_{15} \mathrm{H}_{26} \mathrm{O}_{3}$ & 236 & $277.2[\mathrm{M}+\mathrm{Na}]^{+}$ \\
\hline
\end{tabular}

carbon at $\delta 55.2$, two conjugated carbonyl groups $\delta 188.4$ and at $\delta 180.7$, and a methylene at $\delta 38.2 .^{17}$

For compound (28), a query to the Dictionary of Natural Products database showed 68 additional fungal compounds with the same UV spectrum $\left(\lambda_{\max } 240,279\right.$ and $\left.347 \mathrm{~nm}\right)$ and molecular weight $(\mathrm{m} / \mathrm{z}$. 209.1 for the $[\mathrm{M}+\mathrm{H}]^{+}$ion). Analysis of the ${ }^{1} \mathrm{H},{ }^{13} \mathrm{C}$ and HSQC NMR spectra indicated the presence of a 1,2,4,5-tetrasubstituted benzene ring with ${ }^{1} \mathrm{H}$ signals at $\delta 7.13$ (s, $\left.\mathrm{CH}-5\right)$ and $\delta 6.28$ (s, $\left.\mathrm{CH}-8\right)$. Two methyl groups represented by overlapping singlets at $\delta 1.40\left(\mathrm{~s}, \mathrm{H}_{3} \mathrm{C}-9\right.$ and $\left.\mathrm{H}_{3} \mathrm{C}-10\right)$, one methylene group at $\delta 2.61\left(\mathrm{~s}, \mathrm{CH}_{2}-3\right)$, one carbonyl group at $\delta 193.8$ (C-4), as well as the presence of five quaternary carbons, including two hydroxylated aromatic carbons at $\delta 157.6(\mathrm{C}-$ $7)$ and 141.7 (C-6) and one oxymethine group at $\delta 80.1$ (C-2), were also observed. In the HMBC spectrum of (28), correlations from the methylene group at $\delta 2.61$ (s) to $\mathrm{C}-2\left(\delta_{\mathrm{C}} 80.1\right), \mathrm{C}-9 / \mathrm{C}-10\left(\delta_{\mathrm{C}} 26.8\right)$, $\mathrm{C}-4 \mathrm{a}\left(\delta_{\mathrm{C}} 113.2\right)$ and $\mathrm{C}-4\left(\delta_{\mathrm{C}} 193.8\right)$, confirmed the structure and position of the pyranone ring in the molecule. HMBC correlations from $\mathrm{CH}-5$ at $\delta 7.13$ (s) to $\mathrm{C}-4 \mathrm{a}\left(\delta_{\mathrm{C}} 113.2\right)$ and $\mathrm{C}-8\left(\delta_{\mathrm{C}} 104.6\right)$, and from $\mathrm{CH}-8$ at $\delta 6.28$ (s) to $\mathrm{C}-4 \mathrm{a}\left(\delta_{\mathrm{C}} 113.2\right)$ confirmed the substitution pattern of the 1,2,4,5-tetrasubstituted benzene ring. Compound (28) was identified as 6,7-dihydroxy-2,2-dimethyl-4-chromanone, first synthesized in $1937 .{ }^{38}$ Related compounds displayed antioxidant activity and are used as inhibitors of self-oxidation of various organic substrates such as plastics, lubricants and rubber products often exposed to air during manufacturing processes. ${ }^{38,39}$ Production of (28) by Cochliobolus spp. is its first report from a natural source.

Selected compounds were evaluated in antiviral assays. Compounds $\mathbf{8}, \mathbf{1 8}, \mathbf{2 1}$, harzianopyridone (29) and pyrenocine A (30) displayed moderate to strong antiviral activity (Table 3). Compound (18) also showed moderate activity against strains of hepatitis $C$ virus at a concentration of $2.5 \mu \mathrm{g} \mathrm{mL} \mathrm{L}^{-1}$.

In order to identify the stage of viral replication on which compounds (29) and (30) were active, three different treatments were performed. The first treatment consisted of infecting cells with viruses and incubating them for $1 \mathrm{~h}$, followed by the addition of the compounds. The second treatment consisted of incubating the viruses with the compounds, in order to observe virus inactivation during the viral replication phase. Finally, the addition of compounds to cells prior to viral infection was performed in order to evaluate any effect on viral adsorption. Harzianopyridone (29) was active against HSV-1 during the viral inactivation phase (99\% inhibition), with an $\mathrm{EC}_{50}$ of $0.2 \mu \mathrm{g} \mathrm{mL}^{-1}$, low toxicity $(34 \mu \mathrm{g} \mathrm{mL}-1)$ and high selectivity against HSV-1. Pyrenocine A (30) presented $90 \%$ inhibition of AMPV growth during the viral replication phase, with an $\mathrm{EC}_{50}$ of $63.27 \mu \mathrm{g} \mathrm{mL}^{-1}$, as well as $90 \%$ inhibition of HSV-1 during the viral adsorption phase, with an $\mathrm{EC}_{50}$ of 4.2 $\mu \mathrm{g} \mathrm{mL} \mathrm{L}^{-1}$. Pyrenocine A also displayed both cytotoxic activity $(\sim 3$ to $\left.5 \mu \mathrm{g} \mathrm{mL}^{-1}\right)$ and low selectivity. Both (29) and (30) displayed antiviral activity against HSV-1 KOS (acyclovir resistant HSV-1) virus strain (data not shown). Such result is particularly interesting, considering that the best drug for the systemic treatment of HSV-1 infection is acyclovir, which inhibits viral replication through competitive inhibition of the viral DNA polymerase and chain termination of viral DNA strains. HSV-1 resistance to acyclovir can result from mutations in either the viral TK gene or the viral DNA polymerase gene. This resistance is developed both in vitro and in vivo, and it 
<smiles>[Y]C1(C)CCC[C@](C)(c2ccc(C(=O)O)cc2O)O1</smiles><smiles>COc1cc(OC)c2c(O)c3c(c(-c4c(O)cc5cc6c(c(O)c5c4OC)C(=O)CC(O)([Tl])O6)c2c1)OC(O)([In])CC3=O</smiles><smiles></smiles>

17<smiles></smiles>

22<smiles>CC=CCc1cc(C(=O)O)ccc1O</smiles><smiles>CC1(C)C=Cc2cc(C(=O)O)ccc2O1</smiles>

27<smiles>COc1cc(C(Cc2ccccc2)NC(C)=O)oc(=O)c1</smiles>

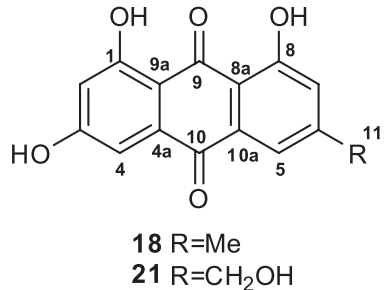<smiles>COc1cc(OC)c2c(O)c3c(=O)cc(I)oc3c(-c3c(OC)cc4cc5oc(C)cc(=O)c5c(O)c4c3OC)c2c1</smiles><smiles>[R17]Oc1c(O[R17])n(O)c2c(=O)c(O)c(/C=C/C)oc12</smiles>

$10 \mathrm{R}_{1}=\mathrm{H}, \mathrm{R}_{2}=\mathrm{Me}$ $15 \mathrm{R}_{1}=\mathrm{Me}, \mathrm{R}_{2}=\mathrm{H}$
$\mathrm{HO}$<smiles>[R]c1cc(C2=C(O)C(=O)C(c3ccc(C)cc3)=C(O)C2=O)ccc1O</smiles>

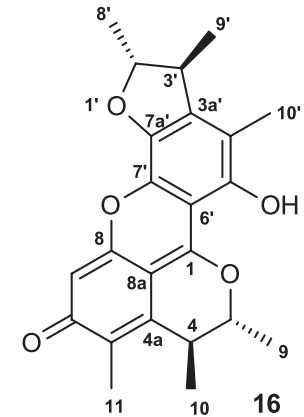<smiles>CC(C)C1NC(=O)c2c1n([N+](=O)[O-])c1ccccc2c1=O</smiles><smiles>[3H]C(O)[C@H]1C(=O)/C(=C(\O)C(C)CCCCCC)C(=O)N1[14CH3]</smiles><smiles>COc1c(Cl)c(O)c2c(c1Cl)CC(C)OC2=O</smiles>

24<smiles>[3H]C1([18F])CC(=O)C=C(C)[C@]1(O)/C=C/C(C)=C\C(=O)O</smiles>

25<smiles>CC1(C)CC(=O)c2cc(O)c(O)cc2O1</smiles>

28<smiles>C/C=C/C[C@H](C)C(=O)c1c(O)c(OC)c(OC)[nH]c1=O</smiles>

29<smiles>CC=CC(=O)c1c(OC)cc(=O)oc1C</smiles>

30<smiles>COc1cc(=O)oc(C)c1C(=O)CC(C)O</smiles>

31

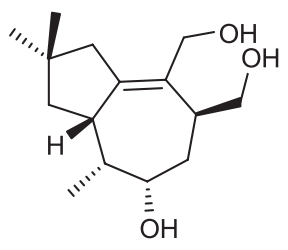

32

Figure 2. Structures of secondary metabolites rapidly identified by UV, LRMS, ${ }^{1} \mathrm{H} N M R$ and, less frequently, by ${ }^{13} \mathrm{C}$ NMR analyses

is very significant in immunocompromised patients. ${ }^{10,40}$ Therefore, new, potent, and selective antiviral agents are necessary to provide alternative HSV-1 treatment choices, with (29) and (30) representing attractive candidates for development as new antivirals. The structural relatedness of (29) and (30) suggests that such structure scaffolds may be of interest for further synthesis and SAR investigations. 
Table 2. Search outcome after taxonomy and HPLC-UV-MS data queries in the Dictionary of Natural Products database

\begin{tabular}{|c|c|c|}
\hline Compounds & $\begin{array}{l}\text { Molecular } \\
\text { weight }(\mathrm{Da})\end{array}$ & $\begin{array}{l}\text { Number of compounds } \\
\text { in the DNP database }\end{array}$ \\
\hline 7 & 264.1 & 58 \\
\hline 8 & 433.0 & 15 \\
\hline 9 & 570.1 & 28 \\
\hline 10 & 253.4 & 9 \\
\hline 11 & 592.1 & 6 \\
\hline 12 & 287.1 & 7 \\
\hline 13 & 340.2 & 45 \\
\hline 14 & 324.2 & 66 \\
\hline 15 & 253.4 & 9 \\
\hline 16 & 380.2 & 41 \\
\hline 17 & 300.2 & 46 \\
\hline 18 & 270.1 & 45 \\
\hline 19 & 256.2 & 59 \\
\hline 20 & 297.3 & 14 \\
\hline 21 & 286.1 & 56 \\
\hline 22 & 286.0 & 56 \\
\hline 23 & 192.2 & 31 \\
\hline 24 & 274.1 & 38 \\
\hline 25 & 264.1 & 58 \\
\hline 26 & 206.2 & 27 \\
\hline 27 & 204.3 & 27 \\
\hline 28 & 208.1 & 68 \\
\hline 29 & 281.2 & 11 \\
\hline 30 & 208.0 & 68 \\
\hline 31 & 226.1 & 60 \\
\hline 32 & 255.2 & 72 \\
\hline
\end{tabular}

Table 3. Overall antiviral activity (\% inhibition) of compounds $\mathbf{8}, \mathbf{1 8}, \mathbf{2 1}$, 29 and 30

\begin{tabular}{lccccc}
\hline Viral strain & $\mathbf{8}$ & $\mathbf{1 8}$ & $\mathbf{2 1}$ & $\mathbf{2 9}$ & $\mathbf{3 0}$ \\
\hline Avian metapneumovirus (AMPV) & $i$ & $68 \%$ & $44 \%$ & $i$ & $98 \%$ \\
Bovine diarrhea virus (BVDV) & $i$ & $42 \%$ & $39 \%$ & $i$ & $i$ \\
Herpes Simplex Virus Type 1 (HSV-1) & $99 \%$ & $44 \%$ & $44 \%$ & $99 \%$ & $98 \%$ \\
\hline
\end{tabular}

$* i=$ inactive.

\section{CONCLUSION}

A strategy for the rapid identification of purified fungal metabolites by HPLC-UV-MS and ${ }^{1} \mathrm{H}$ NMR analyses and, less often, by ${ }^{13} \mathrm{C}$ NMR analysis, enabled the identification of 26 compounds produced by different marine-derived and endophytic fungal strains. Expensive and time-consuming ${ }^{13} \mathrm{C}$ and two-dimensional NMR analyses for identification of known metabolites were avoided. An unreported enantiomer of (+)-5,7-dihydroxy-2-[1-(4-methoxy-6-oxo-6H-pyran-2-yl)-2-phenylethylamino]-[1,4]naphthoquinone, (-)-8, and 6,7-dihydroxy-2,2-dimethyl-4-chromanone (28), are herein reported as natural products for the first time. Evaluation in antiviral assays indicated that pyrenocine A (30) presents significant antiviral activity against HSV-1 in the adsorption phase, and against AMPV in the replication phase. Harzianopyridone (29) showed potent antiviral activity against HSV-1 during the viral inactivation phase coupled with a high selectivity, indicating that, although both compounds (29) and (30) present structural relatedness, their subtle structural differences have to be considered in order to better understand their antiviral mechanism-of-action against HSV-1. Since both pyrenocine
A and harzianopyridone can be obtained via fungal fermentation ${ }^{14,35,34}$ or by synthesis, ${ }^{41,42}$ these compounds clearly represent structural scaffolds worth of investigation for new antiviral leads in drug discovery.

\section{AKNOWLEDGMENTS}

Financial support was provided by the FAPESP BIOTA/ BIOprospec TA grants (2010/50190-2 and 2013/50228-8) awarded to RGSB, and by FAPESP scholarships to LPI (2011/08064-2), MHK (2008/00331-9) and RPMU (2013/23153-7). Further financial support was provided by CNPq scholarships to LPI, ELFF and LKK, and by CAPES scholarships to MCFS, KJ, MSP and SR (BEX 4498-14-3).

\section{REFERENCES}

1. Aly, A. H.; Debbab, A.; Proksch, P.; Fungal Diversity 2011, 50, 3.

2. Ratebab, M. E.; Ebel, R. Nat. Prod. Rep. 2011, 28, 290.

3. Nielsen, K. F.; Larsen, T. O.; Front. Microbiol. 2015, 6, 71.

4. Wolf, D.; Siems, K.; Chimia 2007, 61, 339.

5. El-Elimat, T.; Figueroa, M.; Ehrmann, B. M.; Cech, N. B.; Pearce, C. J.; Oberlies, N. H.; J. Nat. Prod. 2013, 76, 1709.

6. Klitgaard, A.; Iversen, A.; Andersen, M. R.; Larsen, T. O.; Frisvad, J. C.; Nielsen, K. F.; Anal. Bioanal. Chem. 2014, 406, 1933.

7. Wolfender, J.-L.; Marti, G.; Thomas, A.; Bertrand, S.; J. Chromatogr. A 2015, 1382, 136.

8. Ito, T.; Masubuchi, M.; J. Antibiot. 2014, 67, 353.

9. Gaudêncio, S. P.; Pereira, F.; Nat. Prod. Rep. 2015, 32, 779.

10. Antonelli, G.; Turriziani, O.; Int. J. Antimicrob. Agents 2012, 40, 95.

11. Hwang, Y.; Rowley, D.; Rhodes, D.; Gertsch, J.; Fenical, W.; Bushman, F.; Mol. Pharm. 1999, 55, 1049.

12. Rowley, D. C.; Kelly, S.; Kauffman, C. A.; Jensen, P. R.; Fenical, W.; Bioorg. Med. Chem. 2003, 11, 4263.

13. Ióca, L. P.; Allard, P.-M.; Berlinck, R. G. S.; Nat. Prod. Rep. 2014, 31, 646.

14. Kossuga, M. H.; Romminger, S.; Xavier, C.; Milanetto, M. C.; Valle, M. Z.; Pimenta, E. F.; Morais, R. P.; Carvalho, E.; Mizuno, C. M.; Coradello, L. F. C.; Barroso, V. M.; Vacondio, B.; Seleghim, M. H. R.; Cavalcanti, B. C.; Pessoa, C.; Moraes, M. O.; Lima, B. A.; Gonçalves, R.; Bonugli-Santos, R. C.; Sette, L. D.; Berlinck, R. G. S.; Rev. Bras. Farmacogn. 2012, 22, 257.

15. Petrini, O. In Microbial Ecology of leaves; Andrews, J. H.; Hirano, S. S., eds.; Springer-Verlag: New York, 1991, pp. 179-197.

16. Hamasaki, T.; Sato, Y.; Hatsuda, Y.; Agr. Biol. Chem. 1975, 39, 2337.

17. Zhang, Y.; Li, X. M.; Wang, C. Y.; Wang, B. G.; Chinese Chem. Lett. 2007, 18, 951.

18. Priestap, H. A.; Tetrahedron 1984, 40, 3617.

19. Shaaban, M.; Shaaban, K. A.; Abdel-Aziz, M. S.; Org. Med. Chem. Lett. 2012, $2,6$.

20. Hiort, J.; Maksimenka, K.; Reichert, M.; Perovic-Ottstadt, S.; Lin, W. H.; Wray, V.; Steube, K.; Schaumann, K.; Weber, O. H.; Proksch, P.; Ebel, R.; Muller, W. E. G.; Bringmann, G.; J. Nat. Prod. 2004, 67, 1532.

21. Varoglu, M.; Crews, P.; J. Nat. Prod. 2000, 63, 41.

22. Gan, X.; Jiang, W.; Wang, W.; Hu, L.; Org. Lett. 2009, 11, 589.

23. Ye, Y. Q.; Koshino, H.; Abe, N.; Nakamura, T.; Hashizume, D.; Takahashi, S.; Biosci. Biotechnol. Biochem. 2010, 74, 2342.

24. Wakana, D.; Hosoe, T.; Itabashi, T.; Okada, K.; Takaki, G. M. C.; Yaguchi, T.; Fukushima, K.; Kawai, K.; J. Nat. Med. 2006, 60, 279.

25. Moppett, C. E.; J. Chem. Soc. D 1971, 423.

26. Danielsen, K.; Aksnes, D. W.; Francis, G. W.; Magn. Reson. Chem. 1992, 30, 359.

27. Kakinuma, N.; Iwai, H.; Takahashi, S.; Hamano, K.; Yanagisawa, T.; Nagai, K.; Tanaka, K.; Suzuki, K.; Kirikae, F.; Kirikae, T.; Nakagawa, A.; J. Antibiot. 2000, 53, 1247. 
28. Lin, Z. J.; Lu, Z. Y.; Zhu, T. J.; Fang, Y. C.; Gu, Q. Q.; Zhu, W. M.; Chem. Pharm. Bull. 2008, 56, 217.

29. Ren, H.; Tian, L.; Gu, Q.; Zhu, W.; Arch. Pharm. Res. 2006, $29,59$.

30. Bi, Y-M.; Bi, X-B.; Fang, A.; Zhao, Q-R.; Arch. Pharm. Res. 2007, 30, 267.

31. McGahren, W. J.; Mitscher, L. A.; J. Org. Chem. 1968, 33, 1577.

32. Assante, G.; Merlini, L.; Nasini, G.; Specialia 1977, 33, 1556.

33. Abraham, W. - R.; Arfmann, H, - A,; Phytochemistry 1990, 29, 2641.

34. Dickinson, J. M.; Hanson, J. R.; Hitchcock, P. B.; J. Chem. Soc. Perkin Trans. I 1989, 11, 1885.

35. Sato, H.; Konoma, K.; Sakamura, S.; Agric. Biol. Chem. 1979, 43, 2409.
36. Liu, D.-Z.; Fei, W.; Liu, J.-K.; J. Nat. Prod. 2007, 70, 1503.

37. Bhat, H. B.; Vjznkataraman, K.; Tetrahedron 1963, 19, 77.

38. Toledo, T. R.; Dejani, N. N.; Silva Monnazzi, L. G.; Kossuga, M. H.; Berlinck, R. G. S.; Sette, L. D.; Medeiros, A. I.; Mediators Inflammation 2014, Article ID 767061, 11 pg.

39. Nishiyama, T.; Sugimoto, T.; Miyamoto, N.; Uezono, M.; Nakajima, Y.; Polym. Degrad. Stab. 2000, 70, 103.

40. Strasfeld, L.; Chou, S.; Infect. Dis. Clin. North Am. 2010, 24, 413.

41. Tréecourt, F.; Mallet, M.; Mongin, O.; Quéguiner, G.; J. Heterocyclic Chem. 1995, 32, 1117.

42. Ichihara, A.; Kazuo, M.; Sakamura, S.; Tetrahedron 1987, 22, 5245. 